\title{
A new genus and two new species of groundwater paramelitid amphipods from the Pilbara, Western Australia: a combined molecular and morphological approach
}

\author{
Terrie L. Finston', Michael S. Johnson', Stefan M. Eberhard ${ }^{2,3}$, \\ James S. Cocking ${ }^{2,4}$, Jane M. McRae ${ }^{2,4}$, Stuart A. Halse ${ }^{2,4}$ and Brenton Knott ${ }^{1}$ \\ ${ }^{1}$ School of Animal Biology (M092), University of Western Australia, Crawley, Western Australia 6009, \\ Australia. \\ 2 Department of Environment and Conservation, Science Division, P.O. Box 51, Wanneroo, \\ Western Australia 6946, Australia. \\ ${ }^{3}$ Subterranean Ecology Pty Ltd, Suite 8 / 37 Cedric St, Stirling, Western Australia 6021, Australia \\ ${ }^{4}$ Bennelongia Pty. Ltd. 5 Bishop Street, Jolimont, W.A. 6014, Australia.
}

\begin{abstract}
The Pilbara region of Western Australia hosts a diverse fauna in the groundwater, the majority being crustaceans. Specimens of a highly morphologically distinct paramelitid amphipod, clearly representing a new genus, were collected from three tributaries of the Fortescue River basin in the Pilbara. The present study utilised a combined approach, employing molecular markers and morphological characters to assess variation in the new genus and previously described genera of Paramelitidae from the Pilbara. Both molecular and morphological analyses confirmed the distinctiveness of the new specimens, resulting in the description of two new species, Maarrka weeliwollii and M. etheli.
\end{abstract}

KEYWORDS: molecular, morphology, phylogeny, taxonomy.

\section{INTRODUCTION}

A lack of diagnostic characters in which to discriminate species is one of the biggest impediments to advancing the taxonomy of the amphipod fauna of Australia (Bradbury and Williams 1999). The problem becomes magnified when dealing with groundwater species (stygofauna), where the extreme nature of the physical environment exerts strong constraints on some aspects of morphology (Lefébure et al. 2006), resulting in parallel or convergent morphological evolution across disparate taxonomic groups (Culver et al. 1995).

The groundwater amphipod community of the Pilbara, a $178,000 \mathrm{~km}^{2}$ bioregion in north-western Western Australia, is composed of 31 species, all of which have been described since 1995 from north-western Western Australia including the nearby Barrow Island and Cape Range Peninsula (Barnard and Williams 1995; Bradbury and Williams 1996, 1997a; Bradbury 2000, 2002; Finston et al. 2008). Of these 30 species, 18 belong to the family Paramelitidae.
The Paramelitidae were established by Bousfield (1977) and along with three other families, form the superfamily Crangonyctoidea. Williams and Barnard (1988) revised the definition of the superfamily as well as the families composing it, noting that the group had undergone more taxonomic rearrangements than any other group of amphipods in the past 250 years, with most of the changes lacking adequate morphological justification. The most recent summation of the Australian Crangonyctoid fauna was completed by Bradbury and Williams (1999) and included seven genera in the family Paramelitidae, one of which was known from the Pilbara. To date, four genera of paramelitid amphipods are described from the Pilbara, all from subterranean waters or groundwater springs (Pilbarus Bradbury and Williams, 1997a, Molina Bradbury, 2000, Chydaekata Bradbury, 2000, Kruptus Finston et al., 2008), five genera are known from the southwest of Western Australia (Protocrangonyx Nicholls, 1926, Uroctena Nicholls, 1926, Hurleya 
Straškraba, 1966, Totgammarus Bradbury and Williams, 1995, Toulrabia Barnard and Williams, 1995) and five genera are known from eastern Australia (Giniphargus Karman and Barnard, 1979, Austrocrangonyx Barnard and Barnard, 1983, Austrogammarus Barnard and Barnard, 1983, Antipodeus Williams and Barnard, 1988, Chillagoe Barnard and Williams, 1995). Three of the genera from the Pilbara are monospecific. Pilbarus millsi Bradbury and Williams, 1997a and Molina pleobranchos Bradbury, 2000 were both described from the Millstream aquifer in the lower Fortescue River basin, the former from a spring habitat, and Kruptus linnaei Finston et al., 2008 was described from six bores in Spearhole Creek, in the upper Fortescue River basin. In contrast, the fourth genus, Chydaekata, comprises 15 species, 14 of which were described from Ethel Creek near Newman, and the $15^{\text {th }}$ described from Ebathacalby Well on the west side of the Fortescue Marsh, approximately $90 \mathrm{~km}$ to the northwest in the upper Fortescue River basin. Based on the original descriptions and distributions, no species of Chydaekata was found in more than one bore, and six species were described from a single bore. Molecular studies have not supported the finding of multiple species of Chydaekata at Ethel Creek (Finston et al. 2004a; Finston et al. 2007), however, they suggest that across a large part of the Pilbara both Chydaekata and Pilbarus comprise multiple highly divergent lineages associated with distinct tributaries, and these lineages may represent cryptic species within the two genera (Finston et al. 2004b; Finston et al. 2007). Thus, based on molecular and hydrographical patterns it is likely that the 14 species of Chydaekata at Ethel Creek are synonyms and the species at Ebathacalby Well, C. tetrapsis Bradbury, 2000, represents a second species. The existing state of paramelitid taxonomy in subterranean waters of Pilbara may be summarized as follows: three valid species in three genera have been described ( $P$. millsi, $M$. pleobranchos and $K$. linnaei), two are likely to be valid in Chydaekata (C. acuminata Bradbury, 2000 and C. tetrapsis), and other undescribed species are likely to occur.

The high level of morphological variation documented in Chydaekata at Ethel Creek highlights the importance of developing a methodology for separating those characteristics that are biologically meaningful at the species level from those that show natural variation within and among populations. When populations are in sympatry, molecular markers are an efficient way of identifying morphological variation that has no species-level meaning. Molecular markers may also be used to identify cryptic speciation in situations where the pattern of morphological variation does not obviously delineate species. In the present study, both morphological and molecular data were evaluated to provide evidence of the distinctiveness of recently collected paramelitid amphipods that, on first examination, appeared to belong to a new genus. Given the historical difficulties within the Paramelitidae, and a lack of agreement on what constitutes diagnostic characters for the superfamily highlighted by Williams and Barnard (1988), a broader phylogeny is outside the scope of this paper, and we here focus only on 1) diagnosing a new genus of Paramelitidae and 2) developing a dataset of molecular and morphological characters for the Paramelitidae, starting with genera from the Pilbara. To be considered a valid new genus, two criteria were established: 1) the haplotypes must form a monophyletic group, and 2) there must be consistent morphological differences between this monophyletic group and other genera. The evaluation took two forms: 1) phylogenetic analyses were used to test the existing taxonomy and the monophyly of the new paramelitid amphipod specimens and 2) an evaluation of morphological characters was used to identify morphological differences between genetic groups. We use the combined results to describe a new genus and two new species of stygobitic amphipods from the Pilbara.

\section{METHODS}

\section{COLLECTIONS}

Representatives of all described genera of paramelitid amphipods from the Pilbara were collected between 2001 and 2006 and included in the genetic analyses as follows: Molina pleobranchos, one bore in the lower Fortescue River basin, near its type locality aquifer at Millstream; Pilbarus, one bore from the type locality of $P$. millsi at Millstream in the lower Fortescue River basin, and one bore from a tributary in the Ashburton River basin; Chydaekata, four bores from four tributaries in the upper Fortescue River basin, including the type locality for C. acuminata; Kruptus, one bore from the type locality at Spearhole Creek in the upper Fortescue River basin; new genus, six bores from three tributaries in the upper Fortescue River basin, Weeli Wolli Creek, Marillana Creek (conjoined downstream of the sampling areas with Weeli Wolli Creek), and Ethel Creek (Table 1; Figure 1). A specimen of Nedsia sp. Barnard and Williams 1995 (family Melitidae) from a tributary in the Ashburton River basin was sequenced for use as an outgroup. These 14 individuals were sequenced for variation at the mitochondrial genes cytochrome oxidase subunit I (COI) and the large ribosomal RNA subunit (16S) and as well as the nuclear small ribosomal RNA subunit (18S). COI sequences of other Paramelitidae (Uroctena Nicholls, 1926, the undescribed 'Yilgarus' and Paramelitidae sp. 3) are available on Genbank, and were included in a separate analysis of single representatives of each genus using just COI, because data for $16 \mathrm{~S}$ and $18 \mathrm{~S}$ were lacking.

\section{PCR AND SEQUENCING PROTOCOLS}

Whole genomic DNA was extracted from frozen or alcohol-preserved specimens. Specimens stored in 


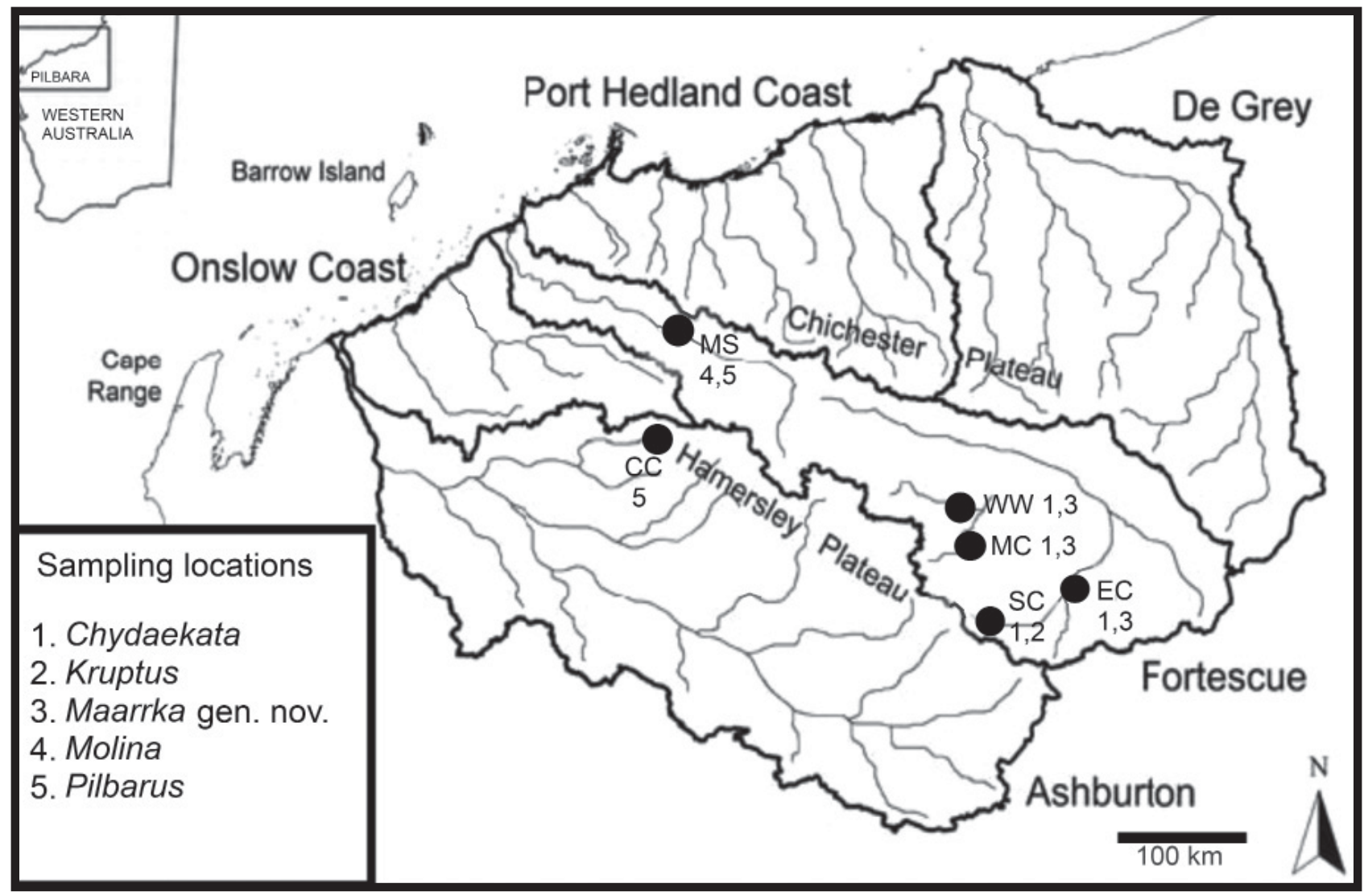

FIGURE 1 Map of the Pilbara showing the location of the five currently described paramelitid genera used in the present study. $\mathrm{CC}=$ Caves Creek, $\mathrm{EC}=$ Ethel Creek, $\mathrm{MC}=$ Marillana Creek, MS = Millstream, $\mathrm{SC}=$ Spearhole Creek, WW = Weeli Wolli Creek. Dark lines indicate river basin boundaries, which are labelled in large type.

alcohol were rinsed twice in a $10 \mathrm{mM}$ Tris solution to remove the alcohol before the extraction process. One or two pereopods were dissected from each individual, and extractions were carried out in $50 \mu \mathrm{l}$ of a proteinase K extraction buffer (Schwenk 1996) for 16 to 20 hours. The resulting extract (final volume approximately $50 \mu \mathrm{l})$ was used directly as the DNA template. Two mitochondrial regions (COI and 16S) and one nuclear region (18S) were analysed for all specimens (see Table 2 for a list of primers). For some samples, internal primers were designed using the software package Primer 3 (Rozen and Skaletsky 2000), and these were used in both the PCR and the sequencing reactions (Table 2). The $25 \mu \mathrm{l}$ PCR reactions used 0.2 mM dNTPs, $3.0 \mathrm{mM} \mathrm{MgCl}, 1 \times$ buffer, 10.0 pmoles of each primer, 1 unit Taq, and $2.5 \mu 1$ template, either at full concentration or at $1 / 10$ dilutions. Sequences were cleaned using the UltraClean ${ }^{\mathrm{TM}}$ PCR Clean-up DNA purification kit (MoBio Laboratories, Inc.) prior to sequencing. The sequencing reaction was carried out using the BigDye V3 Ready Reaction Mix (ABI Prism), and the products were sequenced in both directions on an ABI 373 automated sequencer (Applied Biosystems). Sequences were edited and aligned with GeneDoc (Nicholas and Nicholas 1997), using default settings.

\section{MOLECULAR DATA ANALYSES}

In order to assess the validity of combining data sets from all DNA regions, we tested for the model of sequence evolution that best fit each gene region using ModelTest (Posada and Crandall 1998) and PAUP v4b10 (Swofford 2001) using the Akaike information criteria. Modeltest was run for each gene region separately, and then again on two sets of combined datasets $(\mathrm{COI}+16 \mathrm{~S}$ and COI $+16 \mathrm{~S}+18 \mathrm{~S}$ ). The General Time Reversible model with a significant proportion of invariable sites and gamma distributed rates $(\mathrm{GTR}+\mathrm{I}+\mathrm{G})$ was found to be the best fit for $\mathrm{COI}$ and $16 \mathrm{~S}$, as well as the combinations $\mathrm{COI}+16 \mathrm{~S}$ and $\mathrm{COI}+16 \mathrm{~S}+18 \mathrm{~S}$. The HKY+I model was found to be the best fit for $18 \mathrm{~S}$. Pair-wise (GTR) distances between haplotypes were calculated on the COI data only using PAUP.

Maximum likelihood (ML) analyses with 100 bootstrap replicates were performed in PAUP for the combined gene and separate COI data sets, using the GTR $+\mathrm{I}+\mathrm{G}$ model of sequence evolution and settings, and utilising nearest neighbour branch swapping, with the starting trees obtained by neighbour-joining. Further, MrBayes 3.1.2 (Huelsenbeck and Ronquist 2002) was used on the two data sets $(\mathrm{COI}+16 \mathrm{~S}+18 \mathrm{~S}$ and $\mathrm{COI})$ to 


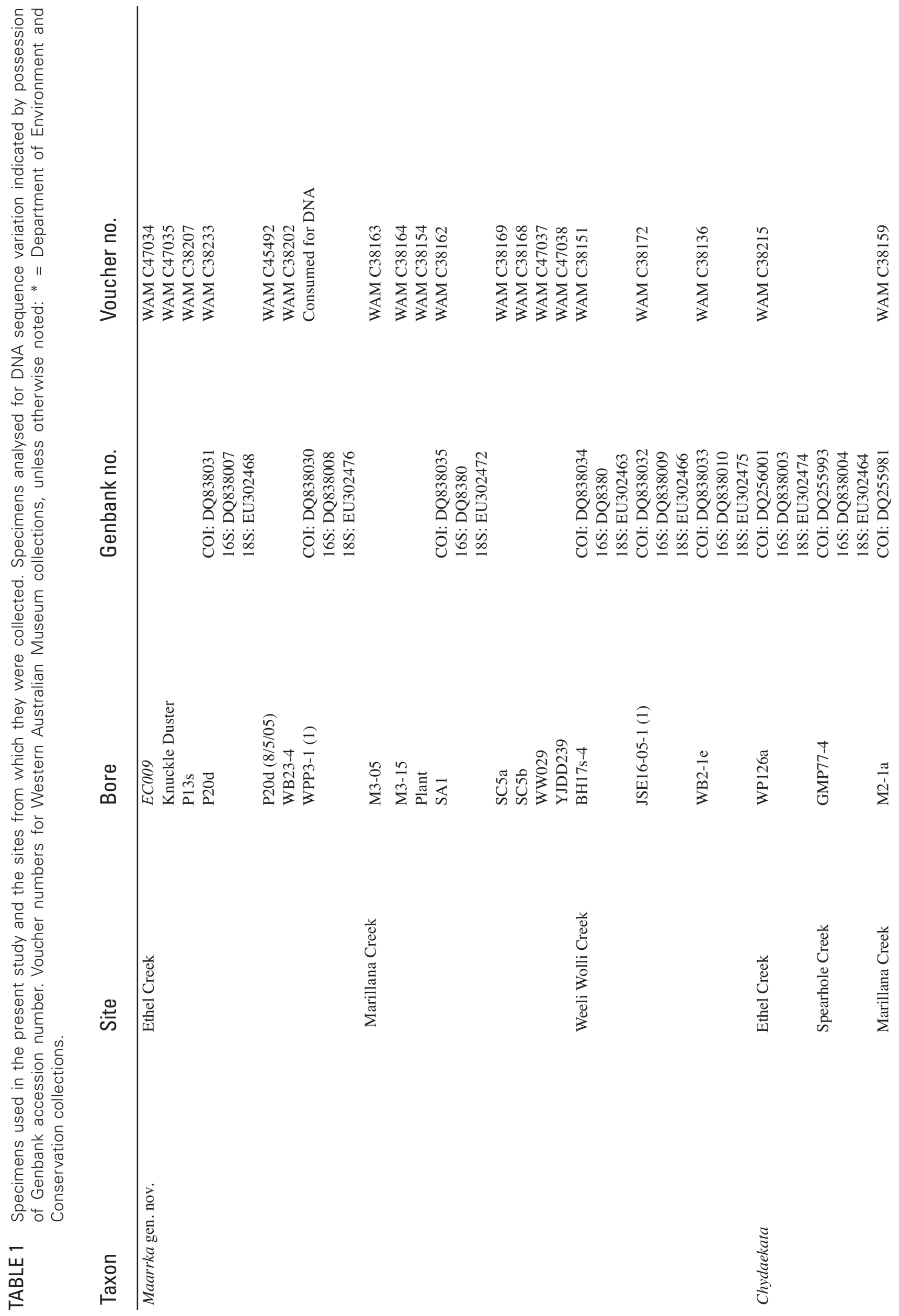




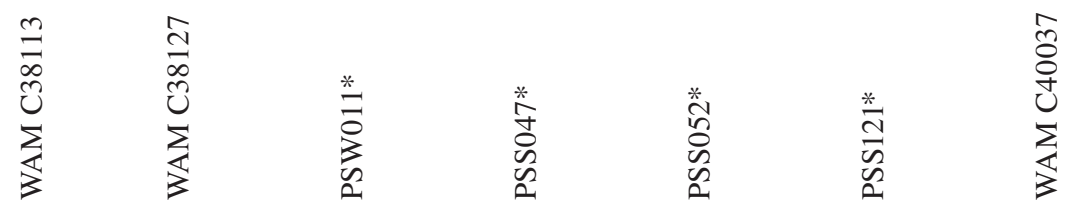

\begin{tabular}{|c|c|c|c|c|c|c|c|}
\hline$\sum_{3}^{\infty}$ & $\frac{\pi}{\underline{0}}$ & $\begin{array}{l}\overline{0} \\
\overline{0} \\
0\end{array}$ & $\begin{array}{l}\tilde{n} \\
\hat{n} \\
\tilde{n} \\
\tilde{a} \\
\alpha\end{array}$ & 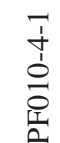 & $\frac{7}{\vec{N}}$ & $\sum_{0}^{0}$ & $\begin{array}{l}\bar{c} \\
\stackrel{1}{c}\end{array}$ \\
\hline
\end{tabular}

\begin{tabular}{|c|c|c|c|c|c|c|c|}
\hline $\begin{array}{l}. \\
\overline{0} \\
\overline{0} \\
\overline{0} \\
\overline{8}\end{array}$ & 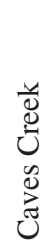 & 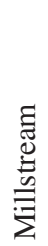 & 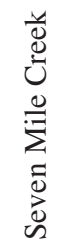 & 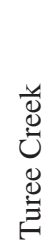 & 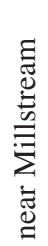 & 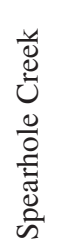 & 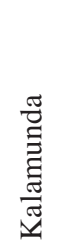 \\
\hline
\end{tabular}


TABLE 2 Primers used for the amplification of paramelitid amphipods from the Pilbara.

$\begin{array}{lll}\text { Reference } & \text { Forward primer } & \text { Reverse primer }\end{array}$

COI

Folmer et al. 1994

LCOI490 5'GGT CAA CAA ATC ATA AAG ATA TTG G 3 ,

HCO2198 5'TAA ACT TCA GGG

TGA CCA AAA AAT CA 3'

Finston et al. 2007

MS3-for 5'TCT GAA TTA AGA

MS3-REV 5'GGT CAC CTC CAC

GCC CCA GGT 3

CAC TAG GA 3'

this study

TC-for 5'TGG GCA AGA ATG CTA GGA AC 3'

TC-REV 5'CGC CAC TAG GGT CAA

AGA AT 3'

$16 S$

modified from

16S-ar 5'CGC CTG TTT AAC

Palumbi et al. 1996

AAA AAC AT 3'

16S-BR 5'CCG GTC TGA ACT CAG

ATC ACG T 3,

this study

16S-PAR-for 5'TAA TTC AAC

ATC GAG GTC 3'

16S-PAR-REV 5'AAT TGA AGG CTG

GAA TGA ATG 3'

$18 \mathrm{~S}$

modified from

G51 5'GGT TGA TCC TGC CAG

Hillis and Dixon 1991

TAG 3'

G52 5'AGG CTC CCT CTC CGG

AAT CGA A 3'

reconstruct the phylogeny using a Bayesian approach The GTR model (nst $=6$ ) with gamma- distributed rates was used for both analyses. Four chains were run simultaneously for $5 \times 10^{6}$ generations, sampling trees every 100 generations. The log-likelihood values were assessed for stationarity by visually inspecting a plot of the p-file values, generated in Excel $\mathbb{C}$. The likelihood values reached stationarity after about 300,000 generations for both the COI and the combined data sets. A majority rule consensus tree was constructed using the 'sumt' command, discarding the first 3,000 trees for both the COI and combined data sets.

\section{MORPHOLOGICAL ASSESSMENT}

A two-step approach was used to assess the taxonomic status of the new genus. First, existing keys and descriptions of the Australian amphipod fauna (Williams and Barnard 1988; Bradbury and Williams 1999; Lowry and Springthorpe 2001) were used to identify the new specimens to the lowest taxonomic level possible. Second, 31 characters [26 diagnostic characters used previously to identify a new genus of stygobitic amphipod from the Pilbara (Finston et al. 2008), and five new characters] were used in a distance analysis. We have attempted to include mainly characters that are diagnostic (present/ absent or measurable) and limit characters that require interpretation of scale or abundance thus being prone to subjectivity. The characters were assembled from generic descriptions and taxonomic keys of Australian freshwater amphipods (Williams and Barnard 1988; Bradbury and Williams 1996, 1997a, 1999; Bradbury 2000) as well as our own observations, and character states were recorded for the 31 characters for representatives of each genus of Paramelitidae described from the Pilbara (Pilbarus, Chydaekata, Molina and Kruptus), as well as the new genus. Hurleya kalamundae Straškraba 1966, a paramelitid groundwater amphipod from south-western Western Australia, which shows superficial morphological similarities to the new genus, was also included to test its relationship to the new genus. A specimen of Nedsia douglasi Barnard and Williams 1995 (family Melitidae), was included as an outgroup. Due to a limited amount of material for examination, character states for Nedsia douglasi and Hurleya kalamundae were determined from the original descriptions. Character states for the remaining species were determined from the examination of preserved material as follows: Pilbarus millsi, four specimens from one bore at Millstream, Chydaekata acuminata, ten specimens from one bore at Ethel Creek, Molina pleobranchos, three specimens from one bore at Millstream, Kruptus linnaei, 14 specimens from five bores at Spearhole Creek, new genus, 11 specimens from eight bores at Weeli Wolli and Marillana Creeks, and eight individuals from five bores at Ethel Creek. Where characters could not be scored from the preserved specimens for Pilbarus, Chydaekata and Molina, states were taken from original descriptions. The remaining nine genera of Paramelitidae were not included in the formal taxonomic analysis but diagnostic morphological differences between them and the new genus were recorded using original descriptions or revisions.

A data matrix of the scores for the 31 characters was constructed using NDE 5.0 (Page 2001), and all characters were included as unordered and unweighted. A distance matrix of mean character differences was 


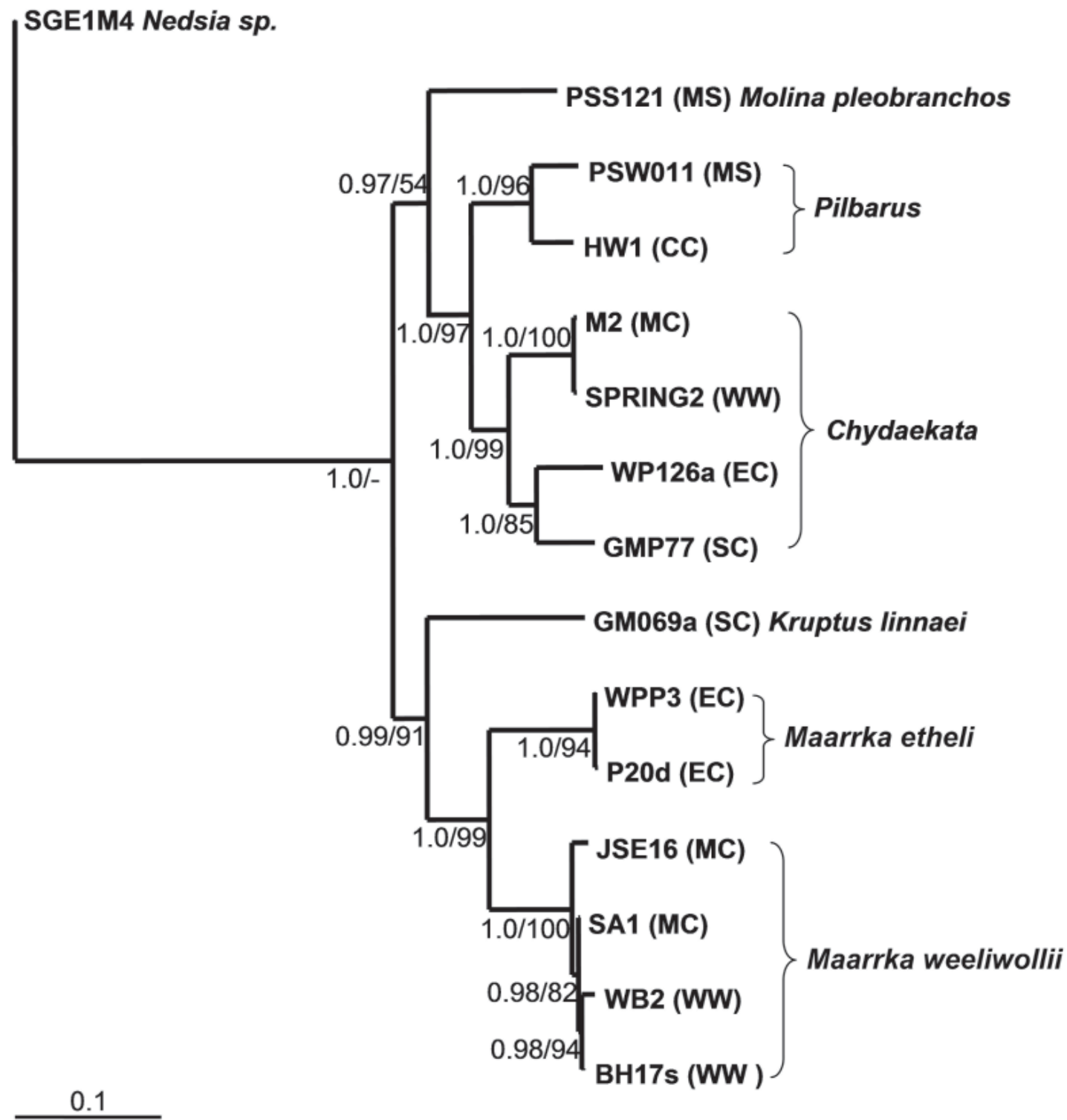

FIGURE 2 Most probable tree for combined CO1, 16S and 18S data, based on Bayesian (shown) and ML analyses. The tree is rooted with a specimen of Nedsia (family Melitidae). Haplotypes labelled with location in tributary: $\mathrm{CC}=$ Caves Creek, $\mathrm{EC}=$ Ethel Creek, $\mathrm{MC}=$ Marillana Creek, $\mathrm{MS}=$ Millstream, $\mathrm{SC}=$ Spearhole Creek, WW $=$ Weeli Wolli Creek. Posterior probabilities and $>50 \%$ support based on 100 bootstrap replicates are shown on branches.

constructed in PAUP using the DISTANCE criterion (Swofford 2001), and multidimensional scaling of the distance matrix was conducted in SYSTAT (Wilkenson 1988) using the MDS module and the Kruskal loss function.

\section{RESULTS}

\section{GENETIC ANALYSES}

Alignment of sequences resulted in $658 \mathrm{bp}, 485 \mathrm{bp}$, and $424 \mathrm{bp}$ fragments of the COI, 16S, and $18 \mathrm{~S}$ regions respectively. Among the 14 ingroup taxa, there were 14 unique haplotypes at COI, 12 at $16 \mathrm{~S}$ and six at $18 \mathrm{~S}$. At $16 \mathrm{~S}$, three individuals of the new genus from Marillana and Weeli Wolli Creeks shared the same haplotype. At $18 \mathrm{~S}$, both specimens of the new genus from Ethel Creek shared the same haplotype, three of the four specimens from Marillana and Weeli Wolli Creeks shared the same haplotype, and most notably, all six specimens of Chydaekata and Pilbarus shared a single haplotype.

Because the addition of the nuclear data set to the mitochondrial alignment did not change the model of sequence evolution with the best fit $(\mathrm{GTR}+\mathrm{I}+\mathrm{G})$, the three regions were combined for the phylogenetic analysis. A second phylogenetic analysis was run containing COI sequences only and included a representative of all available Paramelitidae genera. The ML and Bayesian analyses of the combined data set resulted in nearly identical trees, the only difference 
being the transposition of two haplotypes of the new genus from Weeli Wolli Creek, BH17s and WB21e. Both phylogenies showed six distinct lineages in addition to the outgroup (Figure 2, only the Bayesian tree with the highest posterior probability is shown). Four of the lineages corresponded to the four described genera and two lineages contained haplotypes of the new genus, hereafter referred to as Maarrka gen. nov. Haplotypes of Maarrka were divided into two lineages, which showed an association with hydrological structure. One lineage contained the haplotypes from Ethel Creek (hereafter referred to as Maarrka etheli sp. nov.) and the second contained haplotypes from Weeli Wolli and Marillana Creeks, the conjoined tributaries (hereafter referred to as Maarrka weeliwollii sp. nov.; Figure 2). Lineages within the Pilbarus and Chydaekata clades were also associated with hydrological structure. Bootstrap support for the six lineages was variable, ranging from 85 to $100 \%$ but posterior probabilities were 1.0. Support was particularly high (bootstrap values ranging from 94 to $100 \%$ and posterior probabilities of 1.0) for the lineages of Maarrka, but higher level relationships among genera were less well supported.

In the ML and Bayesian phylogenies of COI haplotypes, which included representatives of each genus of Paramelitidae where sequences were available, each lineage corresponded to a genus. ML bootstrap support was low to moderate, ranging from $<50 \%$ to $72 \%$, whereas posterior probabilities were generally higher, ranging from $<0.5$ to 1.0 . Like the combined tree, the monophyly of Maarrka was well-supported, showing deep genetic divergences between it and the remaining genera (Figure 3). The COI phylogenies showed similarities to the combined tree in the arrangement of lineages, with Molina being the sister lineage to the Pilbarus/Chydaekata group, and Kruptus forming a clade with Maarrka that also included 'Yilgarus' and Paramelitidae sp. 3 (Figure 3).

GTR distances among genera at the $\mathrm{CO} 1$ gene showed that Maarrka was highly divergent from other genera of the paramelitids, showing $21-30 \%$ sequence divergence between it and the other genera (Table 3). Haplotypes of Maarrka differed from 1.0 to $5.2 \%$ between the conjoined Weeli Wolli and Marillana Creeks, while the lineages corresponding to separate tributaries (Marillana/Weeli Wolli versus Ethel Creek), showed 24$25 \%$ sequence divergence. By comparison, haplotypes of Pilbarus from different tributaries differed from one another by $12 \%$, and haplotypes of Chydaekata from different tributaries differed from one another by 15-19 \%. Haplotypes of Chydaekata from the two adjoining tributaries, Weeli Wolli Creek and Marillana Creek, differed by $<1 \%$. Haplotypes of Chydaekata and Pilbarus differed by $19-24 \%$.

\section{MORPHOLOGY}

The specimens from Ethel Creek keyed to the Paramelitidae, having a prominent, biramous third uropod, mandibular palps present, and uropod 1 lacking a robust basio-facial spine. Within the confines of the key, the specimens keyed to Pilbarus millsi, where article 1 of the mandibular palp was much longer than wide, article 2 had few setae, and article 3 lacked $\mathrm{A}$ setae. However, many characteristics of the Ethel Creek specimens differed from $P$. millsi, including differences in the size and shape of the gnathopods, the location of the coxal gills, the extent to which the telson is cleft, the degree of development of the inner lobes of the lower lip, the extent and arrangement of setation on the appendages, especially the gnathopods and uropods, and the presence of calceoli on antenna 2 in the female. While some individuals from Weeli Wolli and Marillana Creeks also keyed to the Paramelitidae, some specimens could not be keyed to a family. The presence of the basio-facial spine on uropod 1 in some individuals is a trait associated with the Melitidae, whereas other traits of the Paramelitidae were also present, such as the presence of a prominent, biramous third uropod and mandibular palps.

Characters used to assess generic relationships are listed in Table 4. The paramelitid genera differed from one another by between three and 21 character states (Table, 5, 6). This translated to distances ranging from 0.097 between the two lineages of Maarrka as well as Pilbarus and Chydaekata to 0.677 between Molina and both lineages of Maarka (Table 6). Multi-dimensional scaling of the distance matrix showed clear separation of Maarrka from the other Pilbara paramelitids, from the melitid, and from Hurleya (Figure 4). Three characters were unique to the paramelitids: the presence of the accessory flagellum on antenna 1 (character 1), the presence of the inner ramus on uropod 3, (character 2 ), and the presence of a prominent mandibular palp (character 3; Table 5). The proportion of the length to width of the first article of the mandibular palp (character 22), the extent of setation on the $2^{\text {nd }}$ article of the mandibular palp (character 23) and the presence of $\mathrm{C}$ setae on the $3^{\text {rd }}$ article of the mandibular palp (character 26) also showed differences between the two families. Maarrka differed from other species of paramelitids by 14 to 21 character differences (Table $5,6)$ and four characters were unique to specimens of Maarrka: the length of the flagellum on the antenna 2 (character 5), the degree to which the telson is cleft (character 13), the shape of article 1 of the mandibular palp (character 22), and the type of setation on uropod 3 (character 30). In particular Maarrka differed from Hurleya by 11 to 14 characters in the Ethel Creek and Marillana/Weeli Wollii Creek specimens, respectively (Table 6). Despite some specimens from Weeli Wolli and Marillana Creeks sharing the presence of a basiofacial spine on uropod 1 with the melitids, they differed from the melitid by 14 characters (Table 5, 6). The two lineages of Maarrka differed by three characters (Table $5,6)$, the presence or absence of a basio-facial spine on uropod 1 (character 14), the presence or absence of inner lobes of the lower lip (character 15), and the presence of absence of calceoli on antennule 2 in females (character 

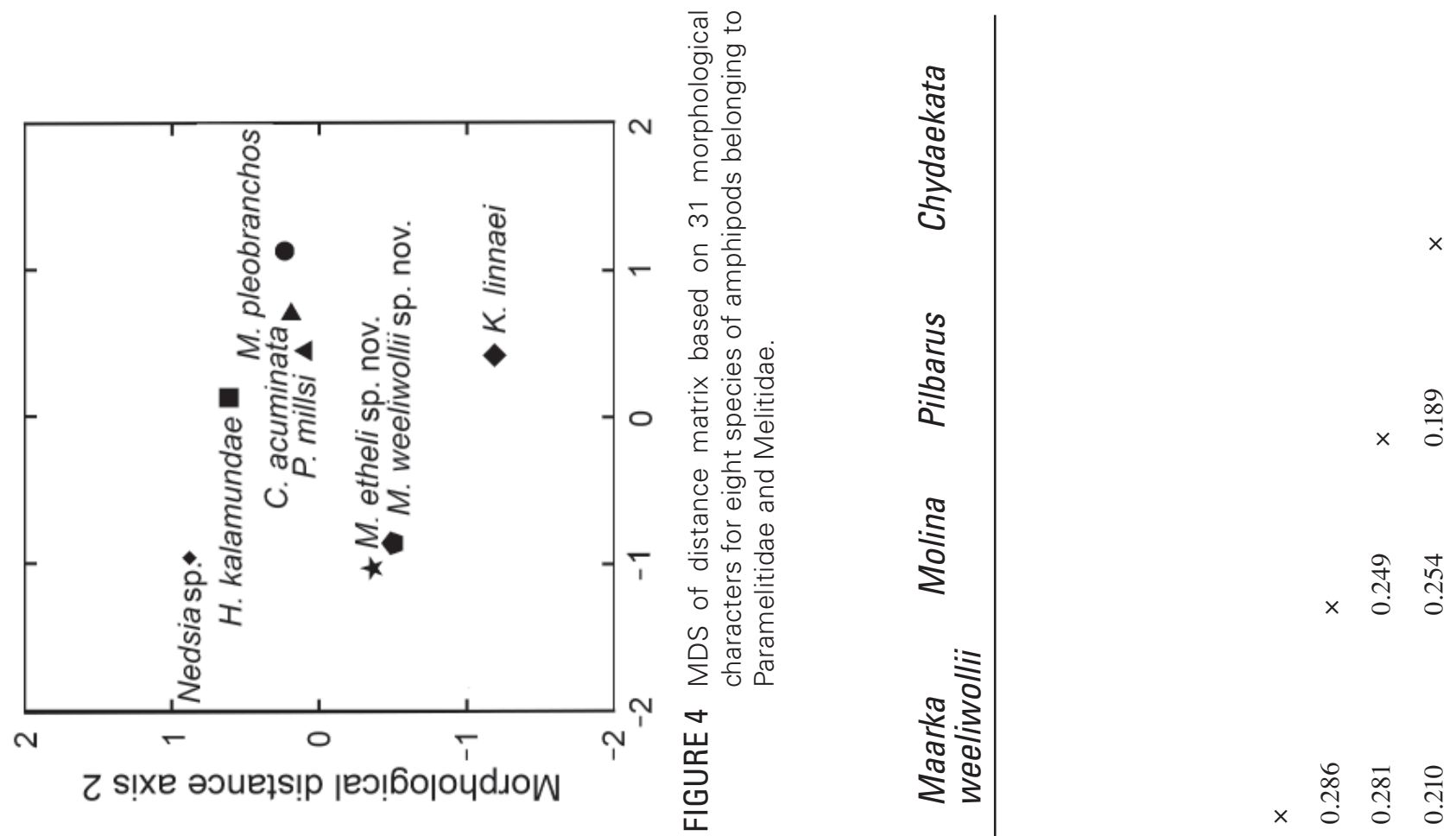

$\frac{1}{\frac{1}{0}}$

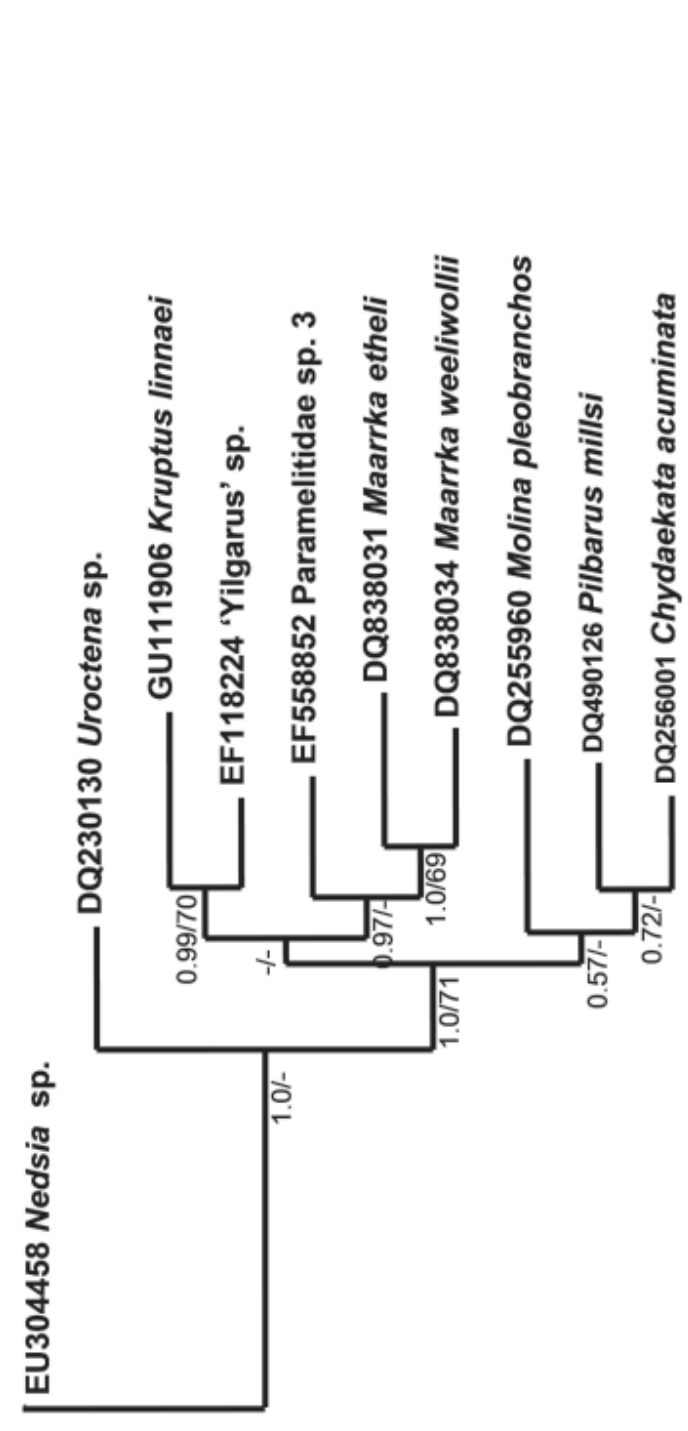

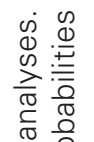

$\frac{\pi}{\frac{\pi}{\pi}}$

$\begin{array}{rrr}\infty & \overrightarrow{0} & 0 \\ & \stackrel{1}{1} & \stackrel{0}{0}\end{array}$

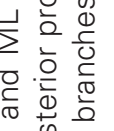

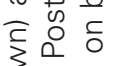

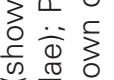

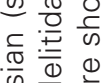

$\frac{0}{\infty} \sum \frac{\Phi}{2}$

ते

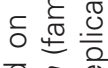

कृ $\frac{\pi}{2} \frac{0}{11}$

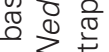

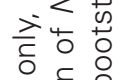

중 응

○

0
0
0
4

®)

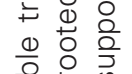

응 은 至

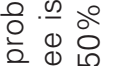

का

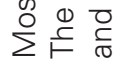

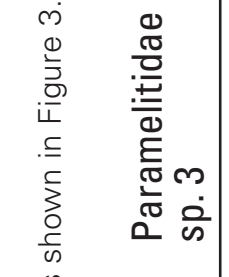

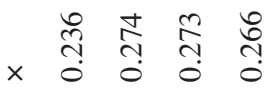

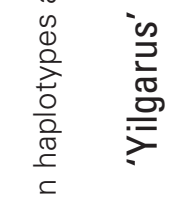

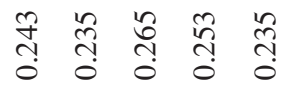

$\begin{array}{llll}x & 0\end{array}$

$\frac{0}{3}$

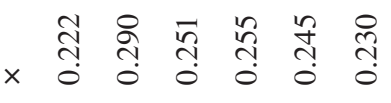

$\times$ तु

$\frac{5}{0}$

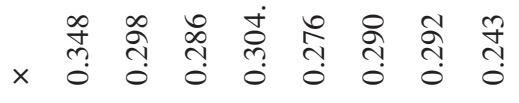

$m$

б|

岕

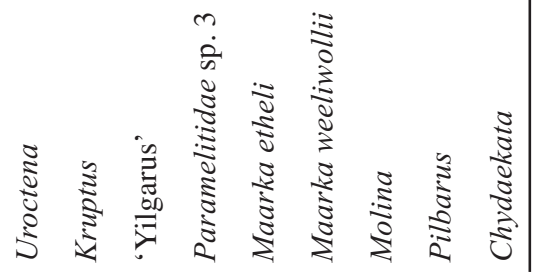


TABLE 4 Characters and character states used for classification of eight species of amphipods belonging to Paramelitidae and Melitidae.

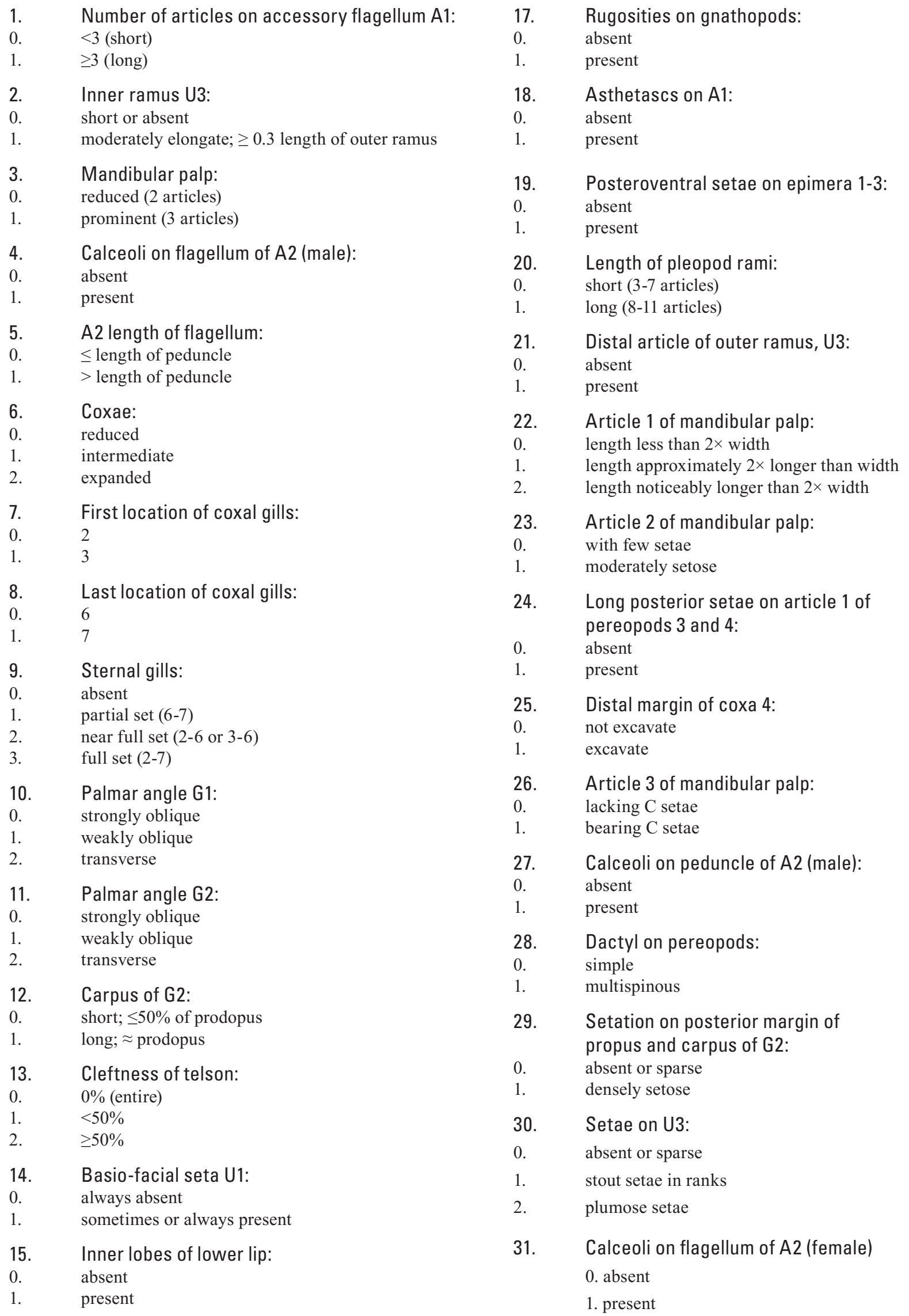

16. Calceoli on peduncle of A2 (female):

$0 . \quad$ absent

1. present 


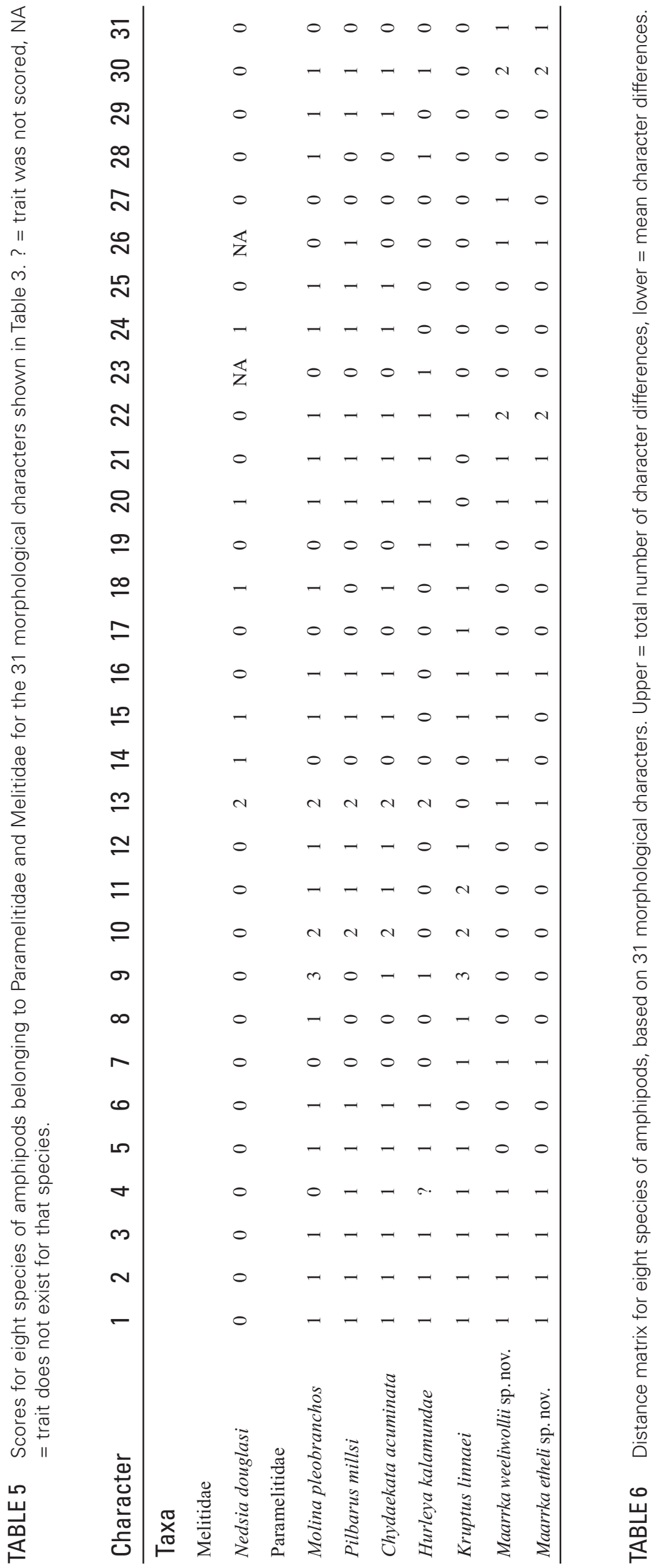

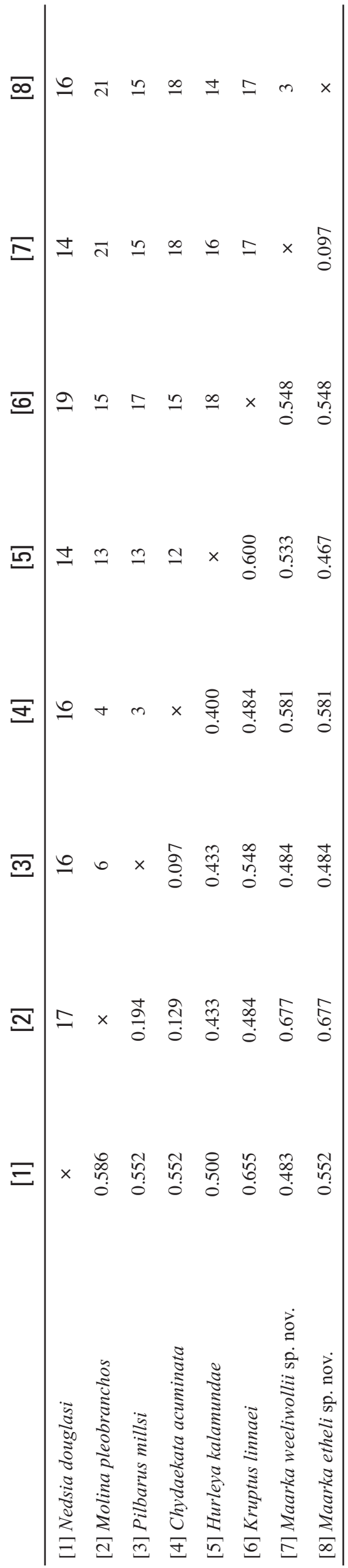


30). Molina, Pilbarus and Chydaekata clustered together (Figure 4), sharing 16 characteristics (Table 6). Pilbarus and Chydaekata were especially close, differing by three characters (Table 5, 6), the presence or absence of sternal gills (character 9), the presence or absence of asthetascs on antenna 1 (character 18) and the presence or absence of $\mathrm{C}$ setae on the $3^{\text {rd }}$ article of the mandibular palp (character 26; Table 5). This level of differentiation is equivalent to the differentiation between the two lineages of Maarrka (Table 6), and with the exception of the relatively close relationship between Molina, Pilbarus and Chydaekata, is substantially less than the differentiation between the other genera of paramelitids (Table 6).

\section{DISCUSSION}

\section{TAXONOMIC IMPLICATIONS}

This study provided morphological and genetic evidence to support the recognition of two new species of paramelitid amphipods, from the Pilbara region of Western Australia, belonging to a single new genus. The genus Maarrka and its two new species met the criteria to be considered valid taxa - the haplotypes of Maarrka formed a monophyletic group showing deep genetic divergence as did both species within the Maarrka lineage, and there were consistent morphological differences between those monophyletic groups.

The genus Maarrka differs from other genera of the Paramelitidae by $>20 \%$ sequence divergence and 14-21 morphological characters (47 to $68 \%$ morphological divergence). The two species of Maarrka differ from each other by $>23 \%$ sequence divergence and three morphological characters $(10 \%$ morphological divergence). In addition, several other characters that were not included in the character matrix also show differences between the two species and may be of taxonomic use (gnathopods 1 and 2 being similar in shape in M. weeliwollii but dissimilar in M. etheli, setal rows being absent from the post-palm of gnathopods 1 in M. etheli and present in M. weeliwollii, differences in the degree of cleftness and ornamentation of the telson). Of particular taxonomic interest is the presence of the basio-facial spine on the first uropod of most specimens of $M$. weeliwollii. The occurrence of this spine is one of the diagnostic features of the family Melitidae (Bradbury and Williams 1999). Despite the presence of this character in some specimens, the genetic evidence and the bulk of the morphological evidence place Maarrka in the Paramelitidae. Gross differences in several morphological characters separate the two families, such as the reduction or absence of structures in the Melitidae, including calceoli on the antennae, the accessory flagellum on antenna 1 , the inner ramus of uropod 3, and the mandibular palp. These features are present and well-developed in the Paramelitidae, Maarrka inclusive. The present study brings into question the phylogenetic importance of the basio-facial spine, and the taxonomic usefulness of the trait, particularly given that it is also present in the paramelitid species Chillagoe thea Barnard and Williams, 1995. The shared presence or absence of characters across diverse taxonomic groups may reflect convergent or parallel evolution, a defining feature of troglomorphy (Culver et al. 1995), The appearance of this character across families highlights the value of establishing a molecular framework to guide the search for taxonomic characters.

\section{RELATIONSHIPS BETWEEN GENERA}

The combined molecular and the separate COI data sets are similar in their placement of Maarrka, placing it as a sister genus to Kruptus in the former and in a clade containing Kruptus and Paramelitidae sp. 3, in the latter. Both analyses support a close affinity of Molina to Pilbarus and Chydaekata. Given the high bootstrap support for the combined analysis, we would expect this phylogeny to be more representative of relationships between genera than is shown by the individual gene data, where bootstrap support is low at deeper levels, however it is important to note that the small number of taxa used in the combined analyses limits the ability to adequately resolve relationships between genera. Instead, this study clearly demonstrates the distinctiveness of the genus Maarrka and has provided a molecular framework on which to build future phylogenetic and taxonomic studies.

The morphological analysis also shows Maarrka to be highly distinct from all four described paramelitid genera from the Pilbara. It differs from Pilbarus, Chydaekata, Molina and Kruptus in the shape and size of the gnathopods, both of which are large and prominent, as well as the reduction in size of other body segments, such as the basipodites, coxae and carpus. Maarrka possess the classic morphological features of stygobitic fauna, being extremely attenuated and vermiform, while Pilbarus, Chydaekata, and Molina are less modified in this regard, possessing longer coxae, greater spinescence, and broader appendages. Kruptus also has reduced spinescence but is less ornamented than Maarrka on several appendages, including the uropods and telson. The close relationship between Molina, Pilbarus and Chydaekata is supported by the morphological analysis, where 16 characters unite the three genera. Molina, Pilbarus, Chydaekata and Maarrka are bound by possessing the distal article of the outer ramus of uropod 3, having telson which are cleft to varying degrees, and the presence of calceoli on the peduncle of the second antennule. Kruptus differs in all these features. Pilbarus, Chydaekata and Molina share many morphological characters such as long coxae, small, similarly shaped gnathopods with transverse or weakly oblique palmar corners and with long carpi, telsons that are deeply cleft, and expanded basipodites of pereopods 5-7.

The morphological analysis suggests that Pilbarus and Chydaekata are closely related. In our data set, just three diagnostic characters differentiate Pilbarus and 
Chydaekata: the absence of sternal gills in Pilbarus, and their presence in Chydaekata; the presence of asthetascs on antenna 1 in males of Chydaekata and their absence in Pilbarus and the presence of $\mathrm{C}$ setae on article 3 of the mandibular palp in Pilbarus and their absence in Chydaekata. The same three characters can be found in Bradbury's (2000) summary of relationships between Chydaekata and Pilbarus. In addition to the three characters, Bradbury (2000) listed several non-diagnostic differences between Pilbarus and Chydaekata such as the degree of robustness of the body in the two genera, the abundance of marginal setae on coxae 5-7, and posterior margins of the pleonites, shape of the palmar angle of the gnathopods, which is described as being transverse in Chydaekata and oblique in Pilbarus, but is described as being 'weakly oblique' in the majority of specimens of Chydaekata. Using our criteria to include mainly those characters that are diagnostic and limit characters that are subjective, Chydaekata and Pilbarus share the same level of morphological differentiation as the two species of Maarrka. In the present study, the COI and combined gene trees show Pilbarus and Chydaekata each to be monophyletic, but the $18 \mathrm{~S}$ data show that the six specimens of Pilbarus and Chydaekata share the same haplotype, including specimens of each genus from their type localities. Efforts to find sympatric populations of the two genera, and a full morphological examination within and between populations will further our understanding of the relationship between Pilbarus and Chydaekata.

\section{SPECIATION OF THE FAUNA}

The presence of distinct lineages of Maarrka in separate tributaries is consistent with the antiquity of the hydrological structure of the Pilbara and with its probable role in isolating populations of the stygobitic fauna and promoting speciation (see Humphreys 1999, 2001; Finston et al. 2007). The Pilbara is characterized by a long history of tectonic stability; the current river systems are thought to have been formed approximately 100 mya (Beard 1998). Increasing aridity and the consequent cessation of regular flow in the rivers during the Tertiary are hypothesized to have forced the epigean fauna into subterranean refuges (Bradbury and Williams 1997b; Humphreys 2001). Recent mtDNA data for Pilbarus and Chydaekata support this hypothesis in the Pilbara, where highly divergent lineages, associated with separate tributaries, were shown to have been evolving independently for millions of years (Finston et al. 2007). Similar patterns of distribution have been observed in tainisopid isopods (Finston et al. 2009; Wilson 2003; Keable and Wilson 2006). In the absence of a clear fossil or geological record, we examined rates of sequence divergence obtained for COI in other taxonomic groups to estimate the age of lineages of Maarrka in the Pilbara. Estimated rates of sequence divergence for $\mathrm{COI}$ in crustaceans range from $1.4 \%$ to $2.6 \%$ per million years (Knowlton et al. 1993; Knowlton and Weigt 1998). Using an average value of $2 \%$ sequence divergence per million years for the CO1 gene, the genus Maarrka separated from the remaining Paramelitidae approximately 10-15 mya. This is consistent with a Pliocene separation and lends further support to hypotheses of hydrological patterns driving evolutionary processes and speciation in the stygobitic fauna of the Pilbara.

\section{FAMILY PARAMELITIDAE BOUSFIELD, 1977}

Maarrka gen. nov.

\section{TYPE SPECIES}

Maarrka weeliwollii sp. nov.

\section{DIAGNOSIS}

Gnathopods 1 and 2 of similar size and very large. 2nd antennae with tongue-shaped calceoli. Prominent accessory flagellum on antenna 1, of three articles, mandibular palp prominent, of three articles. Coxae highly reduced. Carpus of gnathopods 1 and 2 also highly reduced and triangular in shape. Apical article of uropod 3 highly reduced.

\section{DISTRIBUTION}

This genus has been found in Ethel Creek, Roy Hill, Weeli Wolli Creek, Marillana Creek, and Iron Valley, all in the upper Fortescue River drainage, Pilbara, Western Australia.

\section{RELATIONSHIPS}

Maarrka is unlikely to be confused with other amphipods of the Pilbara, owing to the highly distinctive enlarged gnathopods 1 and 2, truncated carpi of the gnathopods, and its distinctive telson, which is only slightly cleft. It also shows diagnostic differences from the remaining Australian paramelitid genera. Maarrka shares large, markedly oblique gnathopods 1 and 2 with Hurleya kalamundae, but differs from that species in many respects. Hurleya differs in the location of the coxal gills, lacks calceoli on the peduncle and flagellum of antenna 2 of the female and possesses posteroventral setae on epimera 1-3. Chillagoe thea possesses a basio-facial spine on uropod 1, like most specimens of $M$. weeliwollii and unlike any other paramelitids, however, lacks the distinct gnathopods of Maarka and also lacks the inner ramus of uropod 3 and calceoli on antenna 2, which are present in $M$. weeliwollii. Similarly, Uroctena and Toulrabia lack calceoli on antenna 2. Giniphargus, Protocrangonyx, Toulrabia and Antipodeus have small gnathopods, and in Antipodeus and Totgammarus, the palms of the gnathopods possess dense spinesence, whereas in Maarrka, the palms possess weak spinesence. Toulrabia lacks the distal article of the outer ramus of uropod 3 while the article is present in Maarrka. The inner ramus of uropod 3 is elongate in Maarrka, $\geq 0.3 \times$ the length of the outer ramus, similar to Kruptus, Molina, Pilbarus and Totgammarus, but differing from the remaining genera. Coxae 1-3 have robust posterior setae in Austrogammarus, which are lacking in Maarrka. 


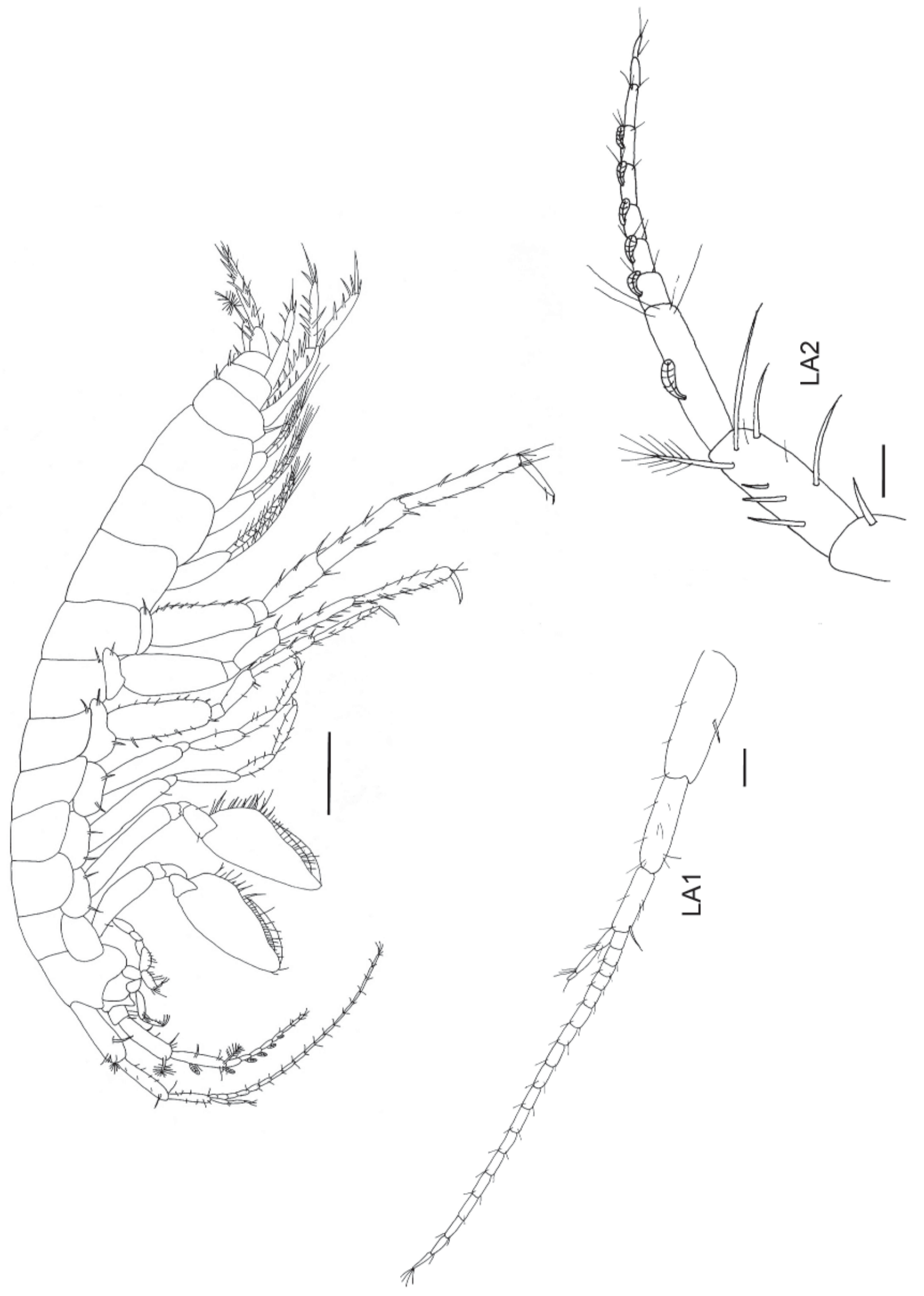




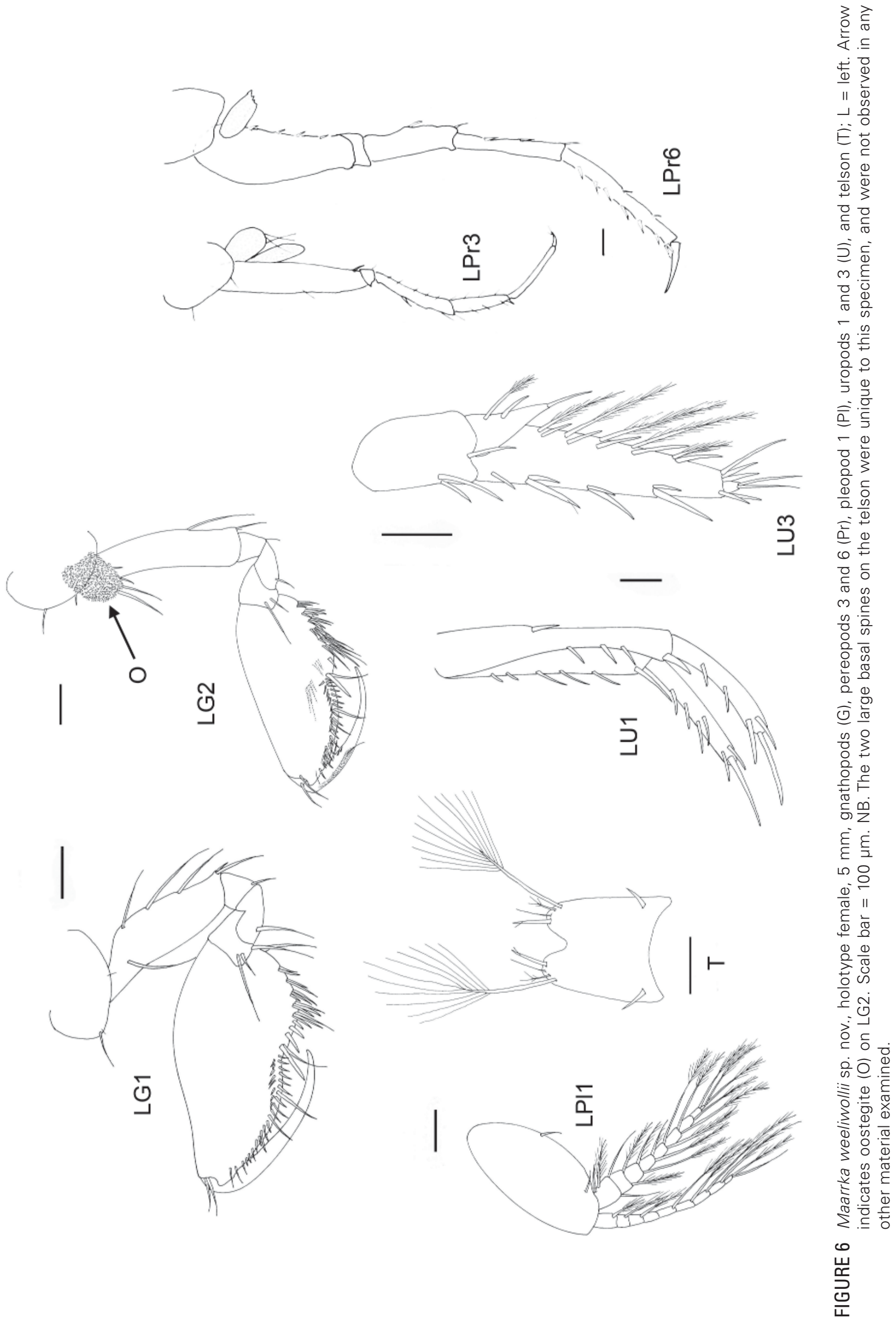




\section{ETYMOLOGY}

The name Maarrka comes from the Yindjibarndi language of the Pilbara region. The name means praying mantis, and is in recognition of the distinctive, mantislike gnathopods characteristic of the genus.

\section{Maarrka weeliwollii sp. nov.}

Figures 5-7

\section{MATERIAL EXAMINED}

\section{Holotype}

Australia: Western Australia, $q$ (5 mm), Pilbara region, Weeli Wolli Creek, bore BH17s-4, 22 $2^{\circ} 5^{\prime} 08^{\prime}$ 'S, 119¹2'02'E, 4 November 2002, G. Humphreys (WAM C38151).

\section{Allotype}

Australia: Western Australia, ô (4 mm), Pilbara region, Marillana Creek, bore SC5, 22 46'29"S, 119¹5'35'E, 6 April 2005, L. Mould, P. Runham (WAM C38169).

\section{Paratypes}

Australia: Western Australia: Pilbara region, Weeli Wolli Creek: 1 ô, bore JSE16-05-1, 2249'34'S, 119¹6’44"E, 6 April 2005, K. Armstrong (WAM C38172); 1 juvenile, bore WB2-1, 22 ${ }^{\circ} 57^{\prime} 15^{\prime} \mathrm{S}$, 11908'43"E, 4 November 2002, G. Humphreys (WAM C38136); Marillana Creek: 2 juvenile, bore Mar3-05-2, 22॰46'20"S, 119¹3'22”'E, 4 April 2005, K. Armstrong (WAM C38163); 1 juvenile, bore M315, 22046'20”S, 119¹3'22”'E 3 November 2003, K. Armstrong (WAM C38164); 1 juvenile, bore Plant-05-2, 2246'28'S, 119¹3'38'E, 3 April 2005, K. Armstrong (WAM C38154); 1 juvenile, bore SA-1, 2246'27'S, 119¹4'13"E, 26 August 2004, K. Armstrong (WAM C38162); 1 ते, 1 juvenile, bore SC-05-1, 22॰46'29'S, 119¹5"35'E, 6 April 2005, K. Armstrong (WAM C38168); 2 juvenile, bore YJDD239, 22 47'25"S, 119 $15^{\prime} 10^{\prime \prime E}, 27$ September 2005, J. Cocking, H. Barron (WAM C47038), 1 q, bore WW029, 2243'59”'S, 119¹8'45’E, 4 November 2009, D. Main, M. Scanlon (WAM C47037)

\section{DIAGNOSIS}

As for genus, but uropod 1 usually having a basiofacial spine. Gnathopods 1 and 2 of similar shape. Setal rows present on margin of post-palm of gnathopod 1 . Apices of telson slightly cleft (approximately 20\%), and with stout seta-spines on inner margins and long setae on outer margins. Calceoli present on the final peduncle of antenna 2 in both male and female. Inner lobes of lower lip moderately well developed in female, asymmetrical in male, setose.

\section{DESCRIPTION}

\section{Female (WAM C38151)}

Bore BH17s-4, Weeli Wolli Creek. Figures 5-7. Head:
First antenna: primary flagellum of 18 articles, basal longest article and bearing two long bi-pinate setae medially on the ventral side, one short bi-pinate seta in the proximal corner and a setal row containing five short setae; long accessory flagellum, reaching $1 / 2$ way along article 5 of the primary flagellum, of three articles, the $1^{\text {st }}$ and $2^{\text {nd }}$ equally long, $3^{\text {rd }}$ short and very narrow. Second antenna: primary flagellum of 8 articles, article 8 very narrow, articles $1-5$ with tongue-shaped calceoli, peduncle article 3 with one calceolus on dorsal surface, peduncle article 2 bearing one long medial bi-pinnate seta and two apical setae on the dorsal side, plus one apical plumose seta and three medial spines on the ventral surface. Right mandible: large palp of three articles, $2^{\text {nd }}$ being largest both in length and breadth. Row of five setae at distal end of article 2. Article 3 has C, D and E setae as follows: seven C setae, D setae form a field covering the breadth of the article, E setae are mainly small, with one large. Incisor has a trifid tooth plus one bifid tooth. Lacinia is a flat plate with four teeth. The setal row is displaced, lying medially, above the lacinia and contains three spurs. The molar is raised with a serrated grinding surface. Right maxilla 1: two articles, $2^{\text {nd }}$ article largest, approximately $2 \times$ longer than article 1 and terminating in three seta-spines, two of which are apical and one which is sub-apical, plus one seta which is sub-marginal. Outer plate terminates in seven spines, three of which are ornamented, plus one asymmetrical trifid tooth. Inner plate short, nude except for two finger-like spines. Right maxilla 2: consists of two lobes of nearly equal size; inner lobe slightly shorter. Dense setules on surface and margin of inner plate and terminating in four long spines, one short spine, and two plumose setae. Outer plate with sparse setation on outer margin and terminating in eight long spines and one short spine. Right maxilliped: four articles in palp, prominent dactyl. Palp: First article with prominent seta-spine on inner margin. Second article with nine long seta-spines on inner margin. Third article, inner margin with four seta-spines two of which are sub-marginal. Lobe at apex of article 3, near the base of article 4, and bearing three long plus one short setaspines. Three long seta-spines near dactyl. Inner plate rectangular, and terminating in three stout sub-marginal apical spines plus one spine, which is sub-marginal and sub-apical. Inner margin with plumose seta-spine below apex. Outer plate markedly bulbous. Inner margin with one stout seta-spine midway. Five stout seta-spines near apex on inner side, which are sub-marginal, plus two along curve of apex. One long seta arises from the surface behind the third seta-spine. Anterior margin with field of long slender setae. Left mandible: palp of three articles, $2^{\text {nd }}$ article largest and with five long submarginal setae at distal end. $3^{\text {rd }}$ article with $\mathrm{C}, \mathrm{D}$ and $\mathrm{E}$ setae as follows: seven $\mathrm{C}$ setae, D setae are a field of fine setules, E setae are four short and one long. Incisor process has single bifid tooth plus chitinised row of two teeth. Lacinia broad with one bifid denticle, the anterior edge of the anterior branch is markedly serrate. Setal row of two spurs and one plumose seta. Grinding 


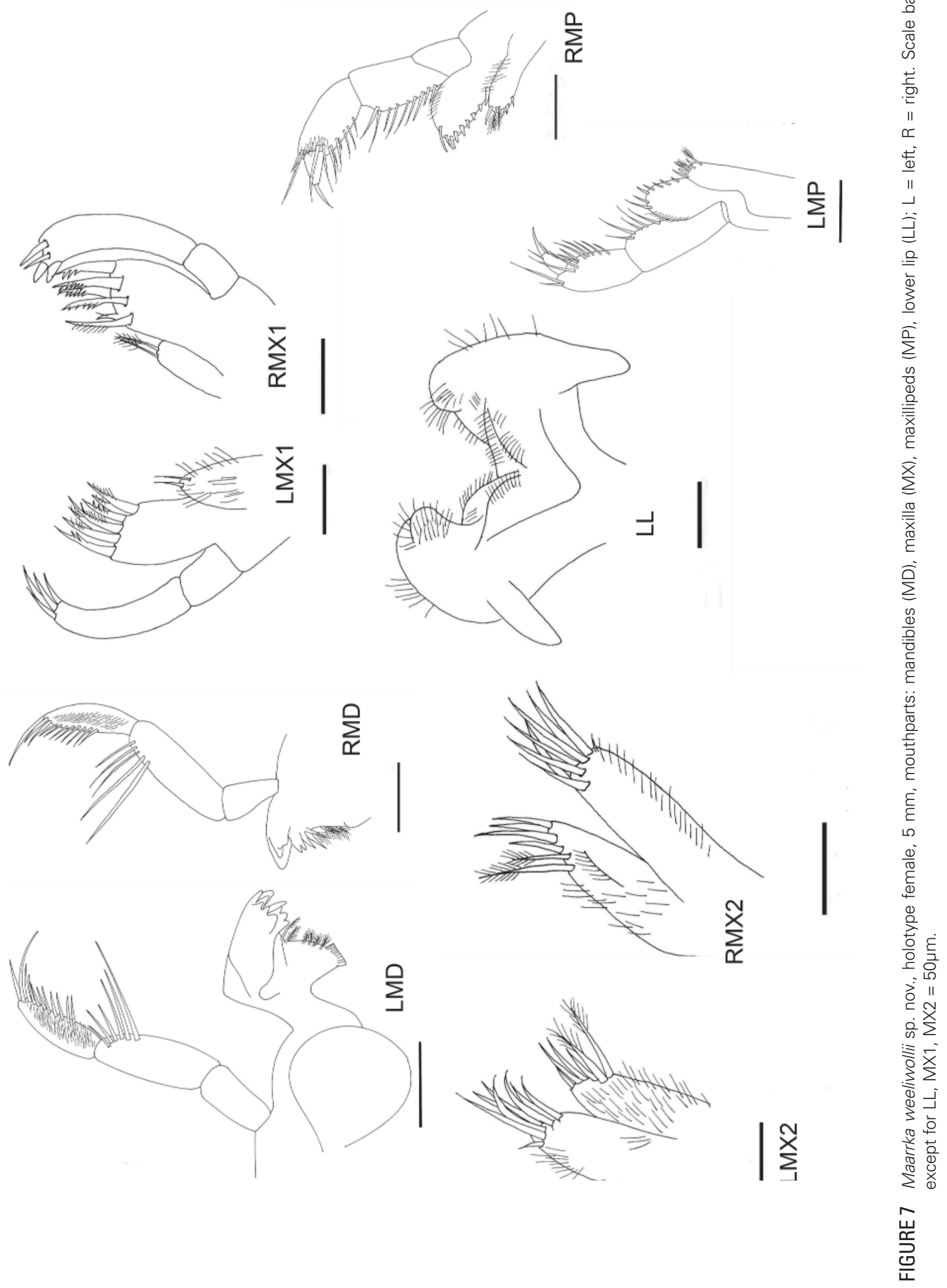


surface of molar poorly developed, triturated, not raised and lacking in setae. Left maxilla 1: palp has two articles, $2^{\text {nd }}$ largest and terminating in two teeth and two seta-spines. Outer plate terminates in seven stout, heavily armed apical teeth plus an eighth tooth that is asymmetrically bifid. Inner plate is short, rectangular, nude except for two finger-like spines. Left maxilla 2: consists of two lobes, inner plate shorter than outer and more pointed at apex than in right. Inner plate with seven stout apical seta-spines and one plumose seta, and sparse setules on surface. Outer plate with eight stout apical seta-spines and a row of long, fine setules along outer margin. Left maxilliped: four articles in palp, prominent dactyl, article 2 largest. First article short, nude except for prominent seta spine at inner distal corner. Second article with nine long seta-spines on inner margin. Outer margin nude. Third article with seven long seta-spines on inner margin. Lobe at apex of article 3 bears three long setae and one shorter setaspine. Article 4 with three long seta spines near nail. Inner plate terminates in three teeth and three spines, one of which is plumose, plus one sub-apical plumose spine. Inner margin with two spines near apical end plus one long seta, which arises medially from the surface. Outer margin lined with row of short setae. Outer plate: inner margin lined with six stout teeth plus two slightly longer teeth on apex, and one seta-spine. Outer margin lined with row of short setae and with one stout setaspine mid-way, which is sub-marginal. Lower lip: Outer margins very sparsely setose, inner margins with setal tufts at apical end. Inner lobes asymmetrical with right lobe rounded and left flatter. Both left and right inner lobes with fine, short setules in rows. Body: vermiform in shape, coxae highly reduced, carapace smooth with little setation. Coxal gills on coxae 2-5. First gnathopod: palm oblique at corner, cutting edge convex followed by a smaller convex lobe. Outer surface nude. Cutting edge with a row of 23 seta-spines, with \#1, 8, and 12 very long. Four robust spines located at corner, following margin of palm, plus three robust spines sub-marginally. Five setal rows on post-palm margin of 2-4 setae each. Coxa very short, scarcely covering base of basis, and asymmetrical, with anterior corner being angular and bearing one seta sub-marginally and posterior corner noticeably rounded. Basis with three long seta-spines on posterior margin. Carpus very short, triangular, embedded in base of propus, and with one long and one short seta on apical margin. Second gnathopod: slightly larger than gnathopod 1, and bearing coxal gill. Cutting edge with a row of seta-spines on both sides. Four robust spines located at corner. Outer surface at corner with four long seta-spines in a setal row. Cutting edge with a row of 22 seta-spines on outer margin, \#8 and 11 are very long. Inner side of cutting edge with 14 seta-spines. Coxa very short with straight ventral margin, scarcely covering base of basis. Basis with one long, slender setaspine. Ischeus long and comparatively narrow. Carpus short, triangular, embedded in base of propus, and with setal tuft on inner side of the posterior lobe. Pereopods: pereopods 3-7 having little setation, 2-5 bear coxal gills and oostegites. Pereopods 5-7 with narrow basipodites. Pereopod 7 markedly long. Dactyl is short on pereopod 3 and 4 , intermediate on pereopod 5 and markedly long on pereopod 6 and 7. Pereopod 6 and 7 with few narrow setae on anterior margin of propus, posterior side few or bare. Oostegites with three long spines. Uropod 1: prominent basio-facial spine. Peduncle with spine on posterior corner. Outer ramus slightly shorter than inner. Setation on outer ramus is slender, with four stout setae on inner margin of inner ramus. Uropod 2: Peduncle nude except for two long spines on distal posterior corner. Outer and inner rami of near equal length; outer raumus terminates in three short and one long setae. Inner ramus terminates in three short and one long setae. Inner margin of inner ramus with two spines. Uropod 3: markedly extended. Inner ramus leaf- shaped, 1/3 - 1/4 length of outer ramus, and with one short robust seta and one plumose seta on the inner margin. Outer ramus has two articles, the first terminating in four short and one long setae and the apical article being very small. Outer margin with five robust setae, inner margin with six plumose setae and six short robust setae. Telson: barely cleft, approximately $15 \%$, apices narrow, but squared off at tips. Inner corner with one small spine and outer corner with one long seta.

\section{Male (WAM C38170)}

Bore SC5, Weeli Wolli Creek. Head: First antenna: primary flagellum of 13 articles, peduncle longest article, long accessory flagellum of three articles, the $1^{\text {st }}$ and $2^{\text {nd }}$ equally long, $3^{\text {rd }}$ short. Second antenna: primary flagellum of 6 articles, article 1 with tongue-shaped calceoli, peduncle with one calceolus. Right mandible: large palp of three articles, $2^{\text {nd }}$ being largest both in length and breadth. Row of three setae at end of article 2. Article 3 has C, D and E setae, E setae are mainly small, with one large. Incisor has three teeth plus one bifid tooth. Lacinia is a flat plate with four denticles and a setal row containing two spurs. Molar lacks setae. Right maxilla 1: palp has two articles terminating in three teeth. Outer plate terminates in four stout apical teeth. Inner plate is short, rectangular, nude. Right maxilla 2: consists of two lobes. Sparse setules on surface and margin of inner plate and terminating in four spines. Outer plate with sparse setation on outer margin and terminating in five spines. Right maxilliped: four articles in palp, fourth article small and conical in shape. Article 2 largest. Outer margins of all articles nude except article 2 possessing a small spine at the distal end. Setation along inner margin of palp sparse and widely separated as follows: article 1: one long setaspine, article 2: four long seta-spines, article 3: three long seta-spines on margin and three sub-marginal setaspines, article 4; two sub-apical setae and one robust spine. Article 3 with one long apical seta. Outer plate approximately symmetrical, paddle-shaped at apex. Five marginal seta-spines on inner margin, which get longer toward apex. Sparse setules on outer margin. One stout seta arises from anterior surface of outer plate, markedly sub-marginal. Inner plate rectangular, and 
with one long stout seta-spine on inner margin. Inner plate with three stout apical teeth and two that are subapical. Left mandible: palp of three articles, $2^{\text {nd }}$ article largest. Row of three setae at end of article 2. $3^{\text {rd }}$ with C, D and E setae. Lacinia broad with five denticles. Incisor process has single bifid tooth plus chitinised row of three spurs. Molar lacking in setae. Left maxilla 1 : palp of two articles, $2^{\text {nd }}$ article largest, greater than $2 \times$ longer than article 1 and terminating in three seta-spines and one seta. Outer plate terminates in six ornamented spines. Inner plate short, nude as in right. Left maxilla 2: consists of two lobes. Sparse setules on surface of inner plate. Inner plate with five stout apical spines, outer plate with six stout apical spines and no setae on outer margin. Left maxilliped: four articles in palp, fourth article small and conical in shape. Article 2 largest. Outer margins of all articles nude. Setation along inner margin of palp sparse and widely separated as follows: article 1: one long seta-spine, article 2: six long setaspines, article 3: two long seta-spines on margin and three sub-marginal seta-spines, article 4; two sub-apical setae and one robust apical spine. Article 3 lobe-like with one long apical seta. Outer plate symmetrical, paddle shaped at apex. Four marginal seta-spines on inner margin, which get longer toward apex. Sparse setules on outer margin. One stout seta arises from anterior surface of outer plate, markedly sub-marginal. Inner plate rectangular and with three stout apical spines and three that are sub-apical, plus one on inner margin approximately $1 / 3$ the distance from apex. Lower lip: Outer lobes: outer margins lacking setation, setal tufts at apices; inner margins densely setose and with a five long setae. Inner lobes: asymmetrical. Right lobe moderately well-developed but absent on left. Row of dense, very short setae on anterior margin of right inner lobe. Body: vermiform in shape, coxae highly reduced, carapace smooth with little setation. Coxal gills on coxae 3-6. First gnathopod: palm oblique at corner, cutting edge convex followed by a smaller convex lobe. Cutting edge with a regularly spaced row of seta-spines. One robust spine located at corner, following margin of palm. Coxa very short, scarcely covering base of basis. Basis with few spines. Carpus very short, triangular, embedded in base of propus. Second gnathopod: slightly larger than gnathopod 1. Similar in shape and spination to gnathopod 1. Pereopods: pereopods 3-7 having little setation, 3-6 bear coxal gills. Pereopods 5-7 with narrow basipodites. Pereopod 7 markedly long. Uropod 1: prominent basio-facial spine. Peduncle with four spines on margin. Outer ramus approximately equal in length to inner. Setation on outer ramus is absent, with one stout seta on inner margin of inner ramus, both terminating in one long seta and three spines. Uropod 2: like uropod 1, but with outer ramus clearly shorter than inner. Inner ramus with two stout setae on inner margin. Uropod 3: markedly extended. Inner ramus leaf- shaped and coming to a point, 1/3 - 1/4 length of outer ramus. Outer ramus has two articles, apical article very small. Outer margin with two plumose setae. Telson: barely cleft, about $20 \%$, apices narrow, and gently rounded at tips. Inner corner with one small spine and outer corner with one long seta.

\section{CHARACTER VARIATION}

The basio-facial spine on uropod 1 was absent in three individuals, one of which was a male and the other two were juveniles and of uncertain sex. The number of robust setae and plumose setae on the inner ramus of uropod 3 varied from one to three and zero to two, respectively among individuals. The cleftness of the telson varied from $15-30 \%$. The number of seta spines and long setae on the apices of the telson differed among individuals, and one individual (BH17s) possessed a pair of prominent sub-marginal basal seta-spines. The shape of the apices of the telson varied from squared to rounded. The number of seta-spine on the cutting edge of the gnathopods varied among individuals.

\section{DISTRIBUTION}

This species occurs in Weeli Wolli Creek and Marillana Creek in the upper Fortescue River drainage, Pilbara, Western Australia.

\section{ETYMOLOGY}

The species name arises from the location of the holotype specimen in Weeli Wolli Creek.

\section{Maarrka etheli sp. nov.}

Figures 8-10

\section{MATERIAL EXAMINED}

\section{Holotype}

Australia: Western Australia, $\circ(7 \mathrm{~mm})$, Pilbara region, Ethel Creek, bore P20d, 2317'31'S, $119^{\circ} 52^{\prime} 12^{\prime}$ 'E, 28 July 2004, L. Mould and J. Lynas (WAM C38233).

\section{Allotype}

Australia: Western Australia, ô (2.5 mm), Pilbara region, Ethel Creek, bore P20d, 2317'31'S, 11952'12”E, 8 May 2005, M. Scanlon and H. Barron (WAM C45492).

\section{Paratypes}

Australia: Western Australia Pilbara region, Ethel Creek, 1 , bore P13s, 2318'59”S, 11950'58”E, 5 November 2005, L. Mould and J. Lynas (WAM C38207); 1 juvenile, bore WB23-4, 2318'46"S, 11951'16"E, 4 November 2005, L. Mould, J. Lynas (WAM C38202); 1 juvenile, bore EC0009, 2250’50”S, $120^{\circ} 07^{\prime} 44^{\prime \prime E}, 23$ July 2009, D. Main, G. Pearson

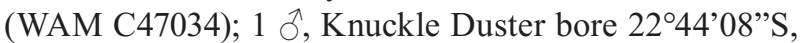
$119^{\circ} 45^{\prime} 55^{\prime}$ 'E, 7 December 2009, M. Scanlon, G. Pearson (WAM C47035).

\section{DIAGNOSIS}

As for genus, but uropod 1 lacking a basio-facial spine. Gnathopods 1 and 2 dissimilar in shape. Setal rows absent from margin of post-palm of gnathopod 1 . Apices of telson moderately cleft (approximately 40\%), and with ornamentation (one or two stout seta-spines 

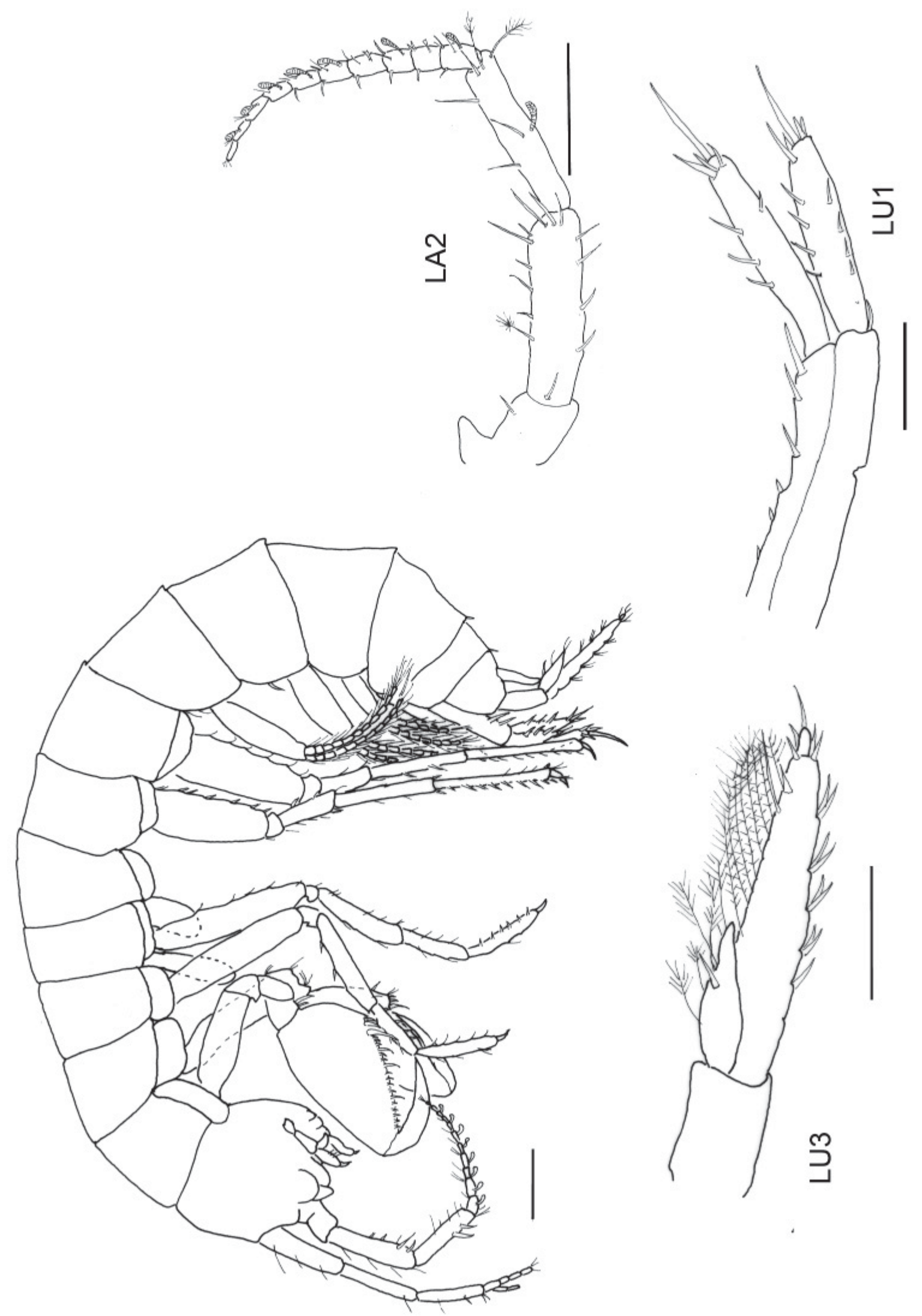

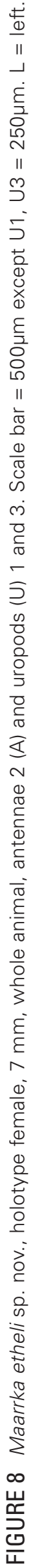




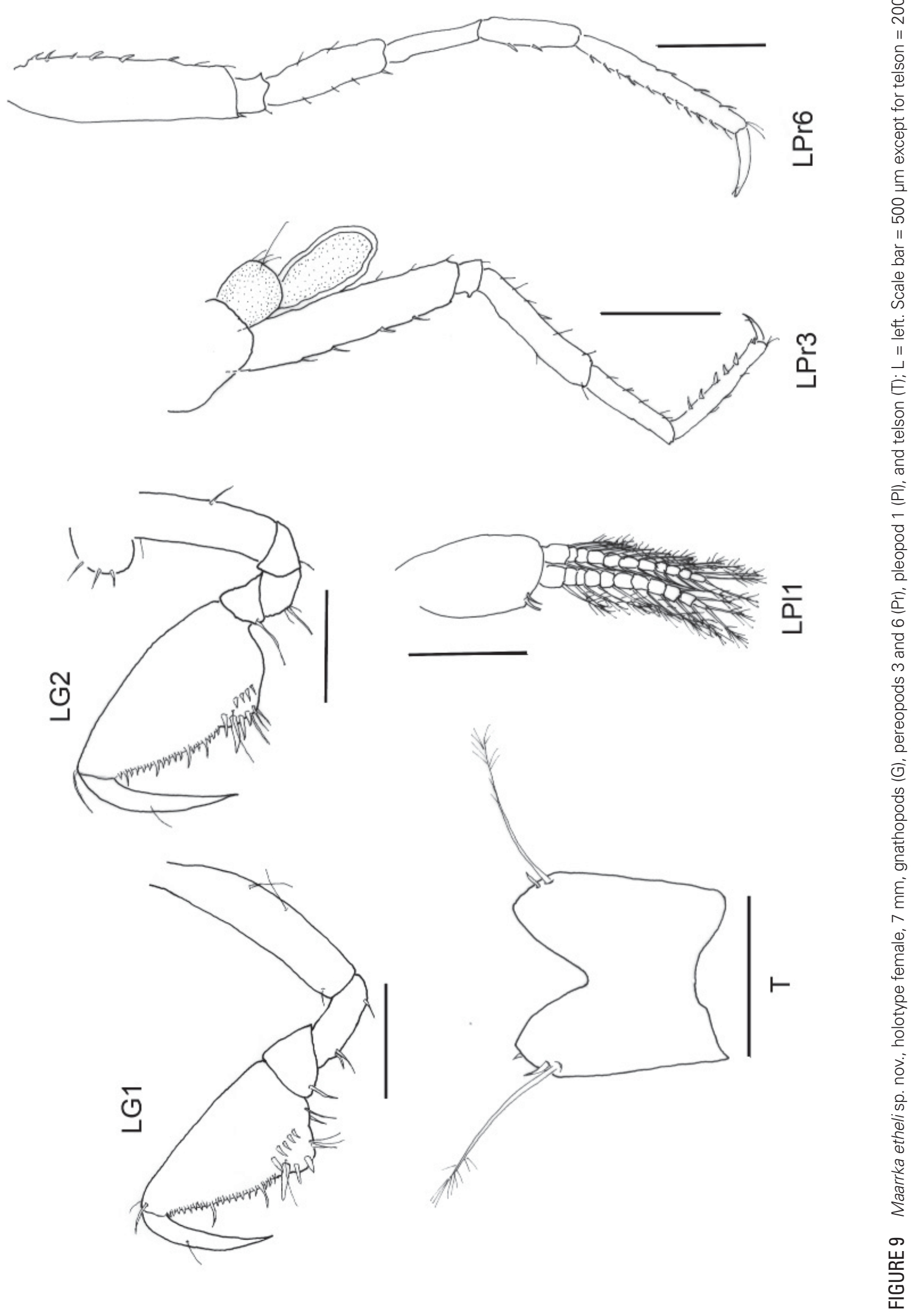




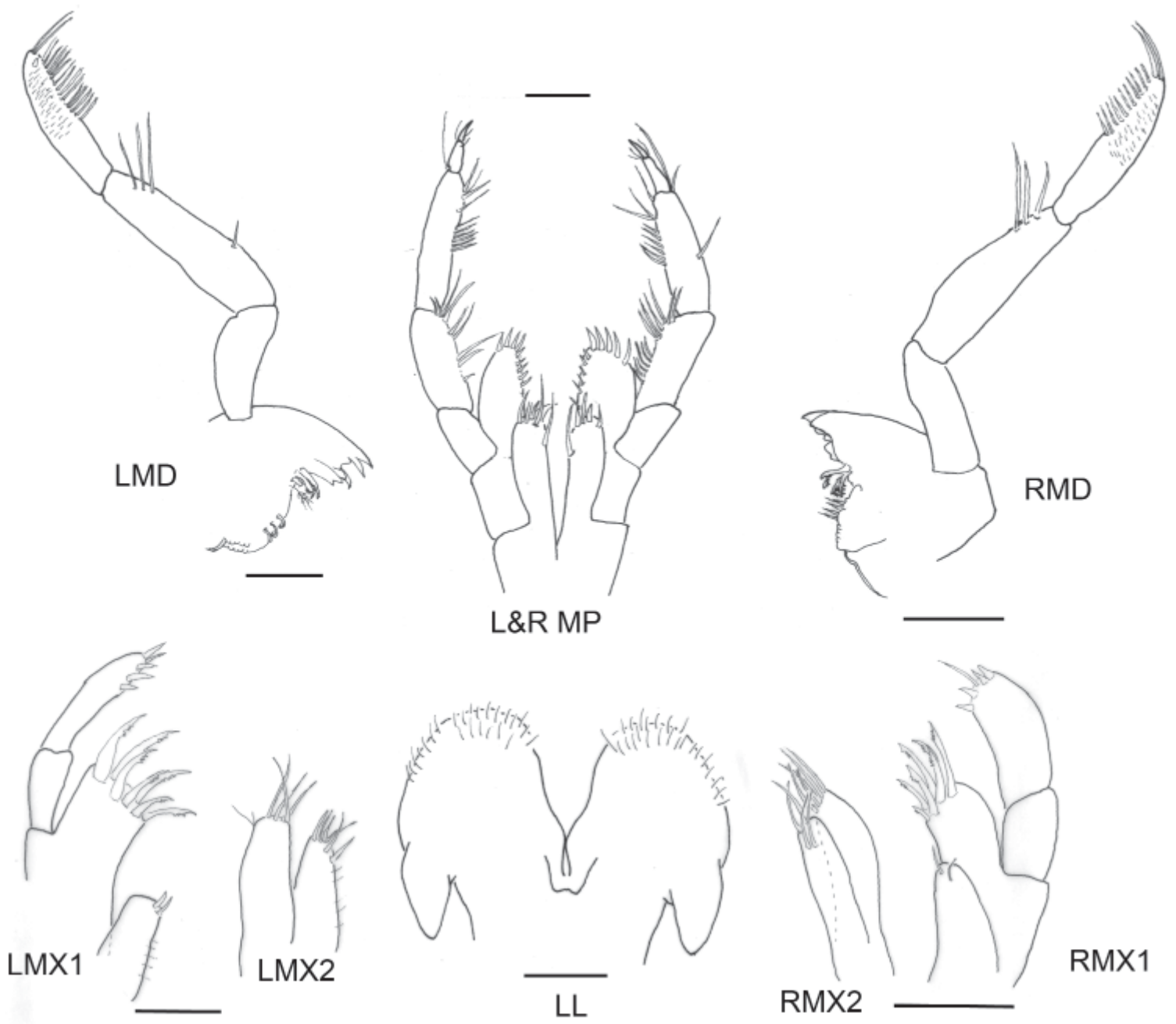

FIGURE 10 Maarrka etheli sp. nov., holotype female, $7 \mathrm{~mm}$, mouthparts: mandibles (MD), maxilla (MX), maxillipeds (MP), lower lip (LL); $L=$ left, $R=$ right. Scale bar $=50 \mu \mathrm{m}$.

and long seta) on outer margin only. Calceoli present on the final peduncle of antenna 2 in female only, lacking in male. Lower lip lacking inner lobes.

\section{DESCRIPTION}

\section{Female, (WAM C38233)}

Bore P20d, Ethel Creek, Figures. 8-10. Head: First antenna: primary flagella broken, peduncle longest article, long accessory flagellum of three articles, the $3^{\text {rd }}$ very short. Second antenna: primary flagellum of ten articles, articles 1-9 with tongue-shaped calceoli with transverse ridges, peduncle with calceolus on mid-mesial surface. Right mandible: large palp of three elongate articles, $2^{\text {nd }}$ article largest and bulbous in shape, $3^{\text {rd }}$ slightly larger than $1^{\text {st }}$. Three long setae at end of article 2. $3^{\text {rd }}$ article with $\mathrm{C}, \mathrm{D}$ and E setae. D setae are short, approximately one-half the width of the article. Lacinia with straight edge and a spine row plus two stout spines. Incisor process has five major projections. Molar process pointed, and lacking a grinding surface. Right maxilla 1: palp has two articles, $2^{\text {nd }}$ article curved, and terminating in three stout spines and one sub-apical seta-spine. Outer plate terminates in five stout apical teeth, two of which are serrated. Inner plate simple, terminating in a row of apical seta-spines. Right maxilla 2: inner and outer plate of relatively equal size and shape, but outer plate slightly larger. Inner plate nude but terminating in four spines. Outer plate terminating in five long spines. Right maxilliped: four articles in palp, article 2 largest, dactyl prominent. Inner plate with two setae and two stout spines, outer plate with 11 seta-spines. Left mandible: prominent, with large palp of three articles, $2^{\text {nd }}$ being largest both in length and breadth and first being the shortest in length. First article nude. Row of three setae at distal end of article 2 near apical surface. Article 3 has C, D and E setae. D setae are long and thick, extending beyond margin of palp. E setae are mainly small, with two large setae at distal end. Incisor process has four teeth, the largest being bifid. Lacinia with four teeth, setal row contains three sensory projections. Prominent conical molar process with small grinding surface, and three plumose setae. Left maxilla 1: palp has two articles, $2^{\text {nd }}$ slightly longer than $1^{\text {st }}$ and curved, terminating in three seta-spines and one seta. Outer plate terminates in seven serrated 
spines. Inner plate terminating in a row of apical setaspines. Left maxilla 2: consists of two lobes, inner plate shorter than outer with weakly pointed apex. Inner plate with seven stout apical seta-spines and sparse setules on surface. Outer plate with eight stout apical seta-spines and a row of long, fine setules along outer margin. Left maxilliped: four articles; dactyl long and prominent. Inner plate rectangular, with two setae and two stout spines. Outer plate bulbous with 11 seta-spines. Lower lip: outer lobes sparsely setose at apical margins, inner lobes absent. Body: vermiform in shape, coxae highly reduced, carapace smooth with little setation. Coxal gills on coxae 3-6. First gnathopod: palm well-defined, straight with well-defined cutting edge. Edge of palm with three stout spines located at outer corner. Inner side of palm with four stout teeth near corner. Setal tuft at corner containing four setae. Single large robust spine sub-marginally. Row of 28 seta-spines along full length of blade, \#5 very long. Inside margin of post-palm nude. Outside edge of blade with 29 seta-spines, \#4, 6, 7, 9, 12, 16, 20, and 25 long. Palm fairly wide but not raised. Margin of post-palm nude. Coxa very short, scarcely covering base of basis. Basis with two long slender setae on apical margin plus two setae sub-marginally at base of article. Carpus very short, triangular, embedded in base of propus. Second gnathopod: slightly larger than gnathopod 1, with well-defined cutting edge. Palm triangular in shape, convex at margin. Inside palm with 1 setal row containing four setae. Inner surface of with four stout teeth and one large sub-marginal tooth. 28 seta-spines in a row at base of blade, $\# 4,12$, and 20 are long. Two short sharp spines at base of blade, not part of row. Outer margin with three large spines plus one sub-marginal spine. Three rounded projections at corner covering the base, inner-most bearing a long seta-spine. Pereopods: pereopods 3-7 having little setation, 3-6 bear coxal gills. Pereopods 5-7 with narrow basipodites. Pereopod 7 markedly long. Dactyl is short on pereopod 3 and 4, intermediate on pereopod 5 and markedly long on pereopod 6 and 7. Pereopod 6 and 7 with dense row of stout teeth on anterior margin of propus, posterior side bare. Oostigites rectangular and slightly rounded at corners, possessing fine setae, present on coxae 3-6. Uropod 1: lacking basio-facial spine. Peduncle with spines on upper outer margin, inner margin has no setation except at inner distal corner where there is one large spine. Outer ramus slightly longer than inner. Both rami end in long stout spine with smaller spines at base. Setation on outer ramus is slender, with two stout setae on outer margin of inner ramus and one on inner margin. Inner ramus has two medial spines. Uropod 2: inner margin of inner ramus with apical robust seta-spines. Uropod 3: markedly extended. Inner ramus leaf- shaped, $1 / 3-1 / 4$ length of outer ramus. Outer ramus has two articles, apical article very small. Telson: cleft about $40 \%$, apices narrow, and roundly pointed. Inner corner lacking spination and outer corner with one long seta and one (left) or two (right) short spines.

\section{Male (WAM C45492)}

Head: juvenile. Bore P20d, Ethel Creek. First antenna: primary flagellum of 14 articles, peduncle longest article, long accessory flagellum of three articles, the $1^{\text {st }}$ and $2^{\text {nd }}$ equally long, $3^{\text {rd }}$ short; accessory flagellum extends to article 3 of the flagellum. Second antenna: primary flagellum of six articles, articles 1-3 with tongue-shaped calceoli with transverse ridges, peduncle lacking calceoli. Right mandible: large palp of three articles, $2^{\text {nd }}$ article largest, $3^{\text {rd }}$ slightly larger than $1^{\text {st }}$. Three long setae at end of article 2 plus one long seta, which is sub-marginal. $3^{\text {rd }}$ article with $\mathrm{C}, \mathrm{D}$ and $\mathrm{E}$ setae. D setae are long and extend beyond the width of the article. Lacinia with serrated edge and a spine row plus two sensory setae. Incisor process has three major projections; the outer two are bifid. Molar process has oval grinding surface with long setae. Right maxilla 1: palp has two articles, $2^{\text {nd }}$ article terminates in two sharp apical teeth and one sub-apical seta-spine. Outer plate terminates in seven stout apical teeth, five of which are heavily ornamented. Inner plate short, rectangular, and nude except for single finger-like spine. Right maxilla 2: consists of two lobes. Sparse setules on surface of inner plate, terminating in stout spines and lacking plumose setae. Outer plate with sparse setation on outer margin and terminating in stout spines. Right maxilliped: four articles in palp, prominent dactyl. Article 2 largest. Left mandible: prominent, with large palp of three articles, $2^{\text {nd }}$ being largest both in length and breadth and first being the shortest in length. Row of three setae at end of article 2. Article 3 has $\mathrm{C}, \mathrm{D}$ and $\mathrm{E}$ setae, E setae are mainly small, with two large setae at distal end. D setae are long and extend beyond the width of the article. Incisor process slightly bifid, with three stout teeth. Lacinia is a triangular plate terminating in a stout point. Lacina lacking in spurs. Prominent bluntly conical molar process with a square grinding surface, lacking ridges. Left maxilla 1: palp has two articles, $2^{\text {nd }}$ slightly longer than $1^{\text {st }}$, terminating in three setaspines and one seta. Outer plate terminates in seven ornamented spines. Inner plate with sparse row of apical setules on inner margin plus two non-plumose setae. Left maxilla 2: consists of two lobes. Sparse setules on surface of inner plate. Inner plate with stout apical teeth and lacking plumose setae. Left maxilliped: four articles, $4^{\text {th }}$ creased tending toward a separation. Inner plate rectangular, outer plate bulbous. Lower lip: outer lobes sparsely setose at apical margins, inner lobes absent. Body: vermiform in shape, coxae highly reduced, carapace smooth with little setation. Coxal gills on coxae 3-6. First gnathopod: palm oblique at corner, cutting edge convex. Cutting edge with a row of seta-spines, one robust seta located at corner, following margin of palm. Coxa very short, scarcely covering base of basis. Basis with few spines. Carpus very short, triangular, embedded in base of propus. Second gnathopod: slightly larger than gnathopod 1. Palm triangular in shape, convex at margin. Pereopods: pereopods 3-7 having little setation, 3-6 bear coxal gills. Pereopods 5-7 with 
narrow basipodites. Pereopod 7 markedly long. Two penes at inner surface of pereopod 7, which barely meet at midline. Uropod 1: lacking basio-facial spine. Peduncle with four spines on outer margin, inner margin has no setation except at inner distal corner where there are two large spines. Outer ramus slightly longer than inner. Both rami end in long stout spine with smaller spines at base. Setation on outer ramus is slender, with two stout setae on outer margin of inner ramus and one on inner margin. Inner ramus has two medial spines. Uropod 2: inner margin of inner ramus with apical robust seta-spines. Uropod 3: markedly extended. Inner ramus leaf- shaped, 1/3 - 1/4 length of outer ramus. Outer ramus has two articles, apical article very small. Telson: cleft about $40 \%$, apices narrow, and roundly pointed. Inner corner lacking spination and outer corner with one long seta.

\section{CHARACTER VARIATION}

The number of pinnate or plumose setae on the inner ramus of uropod 3 varied from zero to three among individuals. The cleftness of the telson varied from $30-40 \%$. The number of seta spines and long setae on the apices of the telson differed among individuals and between the left and right on single individuals, but were always on the outer margin only. The number of seta-spine on the cutting edge of the gnathopods varied among individuals.

\section{DISTRIBUTION}

This species occurs in Ethel Creek in the upper Fortescue River drainage, Pilbara, Western Australia.

\section{ETYMOLOGY}

The species name arises from the location of the holotype specimen in Ethel Creek.

\section{KEY TO PARAMELITIDAE OF THE PILBARA}

1. Outer ramus of uropod 3 lacking distal article; telson entire Kruptus

Outer ramus of uropod 3 with distal article; telson cleft, generally $>15 \%$..... .. 2

2. Prodopus of gnathopods 1 and 2 prominent and much larger than carpus; outer ramus of uropod 3 with plumose setae; coxae reduced Maarrka

Prodopus of gnathopods 1 and 2 small, about the size of carpus; outer ramus of uropod 3 lacking plumose setae; coxae prominent ... 3

3. Calceoli lacking on flagellum of antenna 1 in male; coxal gill present on coxa 7; full set of sternal gills present. Molina

Calceoli present on flagellum of antenna 1 in male; coxal gill lacking on coxa 7; sternal gills absent or present on sternites 6-7 only 4

4. Sternal gills absent, asthetascs absent on flagellum of antenna 1; article 3 of mandibular palp with $\mathrm{C}$ setae Pilbarus

Sternal gills present on sternites 6-7; asthetascs present on flagellum of antenna 1; article 3 of mandibular palp lacking $\mathrm{C}$ setae......... Chydaekata

\section{ACKNOWLEDGEMENTS}

Funding for this project was provided by BHPBilliton Iron Ore, Rio Tinto, and ARC Linkage grant LP0349199. Samples were collected with the assistance of Biota Environmental Sciences, and the Department of Environment and Conservation. Stuart Anstee, Paul Collie, Murray Eagle, Nev Havelberg, Dick Jupp, David Kaljuste, Peter Landman, David Porterfield, Gavin Price, and Peter Waters provided logistical support on and off the mine sites. We sincerely thank John Bradbury for much useful guidance in identifying amphipods, Andrew Storey for providing Hurleya specimens, Garth Humphreys for overall coordination of some of the sampling, Lee Mould for help acquiring bore data, Danny Tang for providing drawing advice to TLF, and Harley Barron, Lee Mould, Phil Runham, and Mike Scanlon for sorting and identifying samples.

\section{REFERENCES}

Barnard, J.L. and Barnard C.M. (1983). Freshwater Amphipoda of the World. Hayfield Associates: Mt. Vernon, Virginia. $830 \mathrm{pp}$.

Barnard, J.L. and Williams, W.D. (1995). The taxonomy of Amphipoda (Crustacea) from Australian fresh waters, Part 2. Records of the Australian Museum 47: 161-201.

Beard, J.S. (1998). Position and development of the history of the central watershed of the Western Shield, Western Australia. Journal of the Royal Society of Western Australia 81: $157-164$.

Bousfield, E.L. (1977). A new look at the systematics of Gammaroidean Amphipoda of the world. Crustaceana, Supplement 4: 282-316

Bradbury, J.H. (2000). Western Australian stygobiont amphipods (Crustacea: Paramelitidae) from the Mt Newman and Millstream regions. Records of the Western Australian Museum, Supplement No. 60.

Bradbury, J.H. (2002). Melitid amphipods from Barrow island, Western Australia Part II- recent discoveries. Records of the Western Australian Museum 21: 83-103.

Bradbury, J.H. and Williams, W.D. (1995). A new genus and species of crangonyctoid amphipod (Crustacea) from Western Australian fresh waters. Transactions of the Royal Society of South Australia 119: 67-74

Bradbury, J.H. and Williams, W.D. (1996). Freshwater amphipods from Barrow Island, Western Australia. Records of the Australian Museum 48: 33-74.

Bradbury, J.H. and Williams, W.D. (1997a). The amphipod (Crustacea) stygofauna of Australia: description of new taxa (Melitidae, Neoniphargidae, Paramelitidae), and a synopsis 
of known species. Records of the Australian Museum 49: 249-341.

Bradbury, J.H. and Williams, W.D. (1997b). Amphipod (Crustacea) diversity in underground waters in Australia: an Aladdin's Cave. Memoirs of the Museum of Victoria 56: 513-519.

Bradbury, J.H. and Williams, W.D. (1999). Key to and checklist of the inland aquatic amphipods of Australia. Technical Reports of the Australian Museum 14: 1-21.

Eberhard, S.M., Halse, S.A. and Humphreys, W.F. (2005a). Stygofauna in the Pilbara region, north-west Western Australia: a review. Journal of the Royal Society of Western Australia 88: 167-176.

Finston, T.L., Bradbury, J.H., Johnson, M.S. and Knott, B. (2004a). When morphology and molecular markers conflict: a case history of subterranean amphipods from the Pilbara, Western Australia. Animal Biodiversity and Conservation 27: 83-94.

Finston, T.L. and Johnson, M.S. (2004b). Geographic patterns of genetic diversity in subterranean amphipods of the Pilbara, Western Australia. Marine and Freshwater Research 55: 619-628.

Finston, T.L., Johnson, M.S., Humphreys, W.F., Eberhard, S. M. and Halse, S.A. (2007). Cryptic speciation in two widespread subterranean amphipod genera reflects historical drainage patterns in an ancient landscape. Molecular Ecology 16: 355-365.

Finston, T.L., Johnson, M.S. and Knott, B. (2008). A new genus and species of stygobitic paramelitid amphipod from the Pilbara, Western Australia. Records of the Western Australian Museum 24: 373-387

Finston, T. L., Francis, C.J. and Johnson, M.S. (2009). Phylogeography of the stygobitic isopod Pygolabis (Malacostraca: Tainisopidae) in the Pilbara, Western Australia: evidence for multiple colonisations of the groundwater. Molecular Phylogenetics and Evolution 52: 448-460.

Folmer, O., Black, M., Hoeh, W., Lutz, R. and Vrijenhoek, R. (1994). DNA primers for amplification of mitochondrial cytochrome c oxidase subunit I from diverse metazoan invertebrates. Molecular Marine Biology and Biotechnology 3: 294-299.

Hillis, D.M. and Dixon, M.T. (1991). Ribosomal DNA: molecular evolution and phylogenetic inference. The Quarterly Review of Biology 66: 411-446.

Holsinger, J.R. (1994). Pattern and process in the biogeography of subterranean amphipods. Hydrobiologia 287: 131-145.

Huelsenbeck, J.P. and Ronquist, F. (2001) MRBAYES: Bayesian inference of phylogeny. Bioinformatics 17: 754-755.

Humphreys, W.F. (1999). Relict stygofaunas living in sea salt, karst and calcrete habitats in arid northwestern Australia contain many ancient lineages. In: The Other 99\%. The Conservation and Biodiversity of Invertebrates (eds. Ponder, W. and Lunney, D.) pp. 219-227. Royal Zoological Society of New South Wales, Mosman.

Humphreys, W.F. (2001). Groundwater calcrete aquifers in the Australian arid zone, the context to an unfolding plethora of stygal biodiversity. Records of the Western Australian Museum Supplement No. 64: 63-83.

Karaman, G.S. and Barnard, J.L. (1979). Classificatory revisions in gammaridean Amphipoda (Crustacea), part 1. Proceedings of the Biological Society of Washington 92: 106-165.
Keable, S.J. and Wilson, G.D.F. (2006). New species of Pygolabis Wilson 2003 (Isopoda, Tainisopidae) from Western Australia. Zootaxa 1116: 1-27.

Knowlton, N. and Weigt, L.A. (1998). New dates and new rates for divergence across the Isthmus of Panama. Proceedings of the Royal Society of London Series B 256: 2257-2263.

Knowlton, N., Weigt, L.A., Solorzano, L.A., Mills, D.K. and Bermingham, E. (1993). Divergence in proteins, mitochondrial DNA and reproductive compatibility across the Isthmus of Panama. Science 260: 1629-1632.

Lefebure, T., Douday, J., Gouy, M., Trontelj, P., Briolay, J. and Gibert J. (2006). Phylogeography of a subterranean amphipod reveals cryptic diversity and dynamic evolution in extreme environments. Molecular Ecology 15: 17911806.

Lowry, J.K. and Springthorpe, R.T. (2001). Amphipoda: Families. Version 1: 2 September 2001. http://www. crustacea.net/.

Nicholas, K.B. and Nicholas, H.B. Jr. (1997). GeneDoc, a tool for editing and annotating multiple sequence alignments. Distributed by the author. www.psc.edu/biomed/genedoc

Nicholls, G.R. (1926). Description of a new genus and two new species of blind freshwater amphipods from Western Australia. Journal of the Royal Society of Western Australia 12: $105-111$.

Page, R.D.M. (2001). Nexus Data Editor for Windows. http//:taxonomy/zoology/gla.ac.uk/rod/rod.html

Page, T.J., Humphreys, W.F. and Hughes, J.M. (2008). Shrimps down under: evolutionary relationships of subterranean crustaceans from Western Australia (Decapoda: Atyidae: Stygiocaris). PLoS One 3: 1-12.

Palumbi, S.R., Martin, A., Romano, S., McMillan, W.O., Stice, L. and Grabowski, G. (1996). The Simple Fool's Guide to $P C R$. Kewalo Marine Laboratory and University of Hawaii: Honolulu.

Posada, D. and Crandall, K.A. (1998). Modeltest: testing the model of DNA substitution. Bioinformatics 14: 817-818

Rozen, S. and Skaletsky, H.J. (2000). Primer3 on the WWW for general users and for biologist programmers. In: Bioinformatics Methods and Protocols: Methods in Molecular Biology (eds. Krawetz, S. and Misener S.) pp 365-386. Humana Press: Totowa, New Jersey.

Schwenk, K. (1996). Evolutionary genetics of Daphnia species complex, hybridism in syntopy. Publication 2231, Netherlands Institute of Ecology, Centre for Limnology: Neuwersluis, The Netherlands.

Straškraba, M. (1966). Hurleya kalamundae n. g. n. sp. (Amphipoda: Gammaridae) from subterranean waters of Western Australia. International Journal of Speleology $\mathbf{2}$ : 291-295.

Swofford, D.L. (2001). PAUP*, phylogenetic analysis using parsimony (*and other methods). Version 4.0b10. Sinauer: Sunderland, Massachusetts.

Wilkinson, L. (1988). SYSTAT: The System for Statistics. SYSTAT, Inc.: Evanston, Illinois.

Williams, W.D. and Barnard, J.L. (1988). The taxonomy of crangonyctoid Amphipoda (Crustacea) from Australian fresh waters: foundation studies. Records of the Australian Museum, Supplement 10: 1-180.

Wilson, G.D.F. (2003). A new genus of Tainisopidae fam. nov. (Crustacea, Isopoda) from the Pilbara, Western Australia. Zootaxa 245: 1-20.

MANUSCRIPT RECEIVED 9 APRIL 2010; ACCEPTED 3 FEBRUARY 2011. 